\title{
Seasonal patterns of surface inorganic carbon system variables in the Gulf of Mexico inferred from a regional high-resolution ocean biogeochemical model
}

\author{
Fabian A. Gomez ${ }^{1,2,3}$, Rik Wanninkhof ${ }^{2}$, Leticia Barbero ${ }^{4,2}$, Sang-Ki Lee ${ }^{2}$, and Frank J. Hernandez Jr. ${ }^{5}$ \\ ${ }^{1}$ Escuela de Ciencias del Mar, Pontificia Universidad Católica de Valparaíso, \\ Avenida Altamirano 1480, Valparaiso, Chile \\ ${ }^{2}$ NOAA Atlantic Oceanographic and Meteorological Laboratory, \\ 4301 Rickenbacker Causeway, Miami, FL 33149, USA \\ ${ }^{3}$ Northern Gulf Institute, Mississippi State University, Stennis Space Center, MS 39529, USA \\ ${ }^{4}$ Cooperative Institute for Marine and Atmospheric Studies, University of Miami, \\ 4600 Rickenbacker Causeway, Miami, FL 33149, USA \\ ${ }^{5}$ Division of Coastal Sciences, University of Southern Mississippi, \\ 703 East Beach Drive, Ocean Springs, MS 39564, USA
}

Correspondence: Fabian A. Gomez (fabian.gomez@pucv.cl)

Received: 28 October 2019 - Discussion started: 7 November 2019

Revised: 6 February 2020 - Accepted: 20 February 2020 - Published: 31 March 2020

\begin{abstract}
Uncertainties in carbon chemistry variability still remain large in the Gulf of Mexico (GoM), as data gaps limit our ability to infer basin-wide patterns. Here we configure and validate a regional high-resolution ocean biogeochemical model for the GoM to describe seasonal patterns in surface pressure of $\mathrm{CO}_{2}\left(p \mathrm{CO}_{2}\right)$, aragonite saturation state $\left(\Omega_{\mathrm{Ar}}\right)$, and sea-air $\mathrm{CO}_{2}$ flux. Model results indicate that seasonal changes in surface $p \mathrm{CO}_{2}$ are strongly controlled by temperature across most of the GoM basin, except in the vicinity of the Mississippi-Atchafalaya river system delta, where runoff largely controls dissolved inorganic carbon (DIC) and total alkalinity (TA) changes. Our model results also show that seasonal patterns of surface $\Omega_{\mathrm{Ar}}$ are driven by seasonal changes in DIC and TA, and reinforced by the seasonal changes in temperature. Simulated sea-air $\mathrm{CO}_{2}$ fluxes are consistent with previous observation-based estimates that show $\mathrm{CO}_{2}$ uptake during winter-spring, and $\mathrm{CO}_{2}$ outgassing during summer-fall. Annually, our model indicates a basinwide mean $\mathrm{CO}_{2}$ uptake of $0.35 \mathrm{~mol} \mathrm{~m}^{-2} \mathrm{yr}^{-1}$, and a northern GoM shelf $(<200 \mathrm{~m})$ uptake of $0.93 \mathrm{~mol} \mathrm{~m}^{-2} \mathrm{yr}^{-1}$. The observation and model-derived patterns of surface $p \mathrm{CO}_{2}$ and $\mathrm{CO}_{2}$ fluxes show good correspondence; thus this study con-
\end{abstract}

tributes to improved constraints of the carbon budget in the region.

\section{Introduction}

The global ocean is absorbing approximately one-third of the anthropogenic $\mathrm{CO}_{2}$ released into the atmosphere from fossil fuel burning (e.g., Sabine et al., 2004; Gruber et al. 2019), resulting in a sustained decline in seawater $\mathrm{pH}$ and the saturation state of calcium carbonate (e.g., Orr et al., 2005). This process, commonly known as ocean acidification, has deleterious impacts on calcifying organisms, such as corals, coralline algae, shellfish, and shell-forming plankton (Doney, 2012). Ocean acidification is disturbing marine ecosystems worldwide (e.g., Mostofa et al., 2016), demanding urgent societal responses to address coastal ecosystem impacts. Therefore, a better understanding of the past and current carbon system variability at global and regional scales is crucial to better monitor and predict ocean and ecosystem responses to enhanced $\mathrm{CO}_{2}$ levels.

Significant progress has been made in the understanding of ocean carbon dynamics in coastal waters of the United 
States during the last 15 years or so. However, many aspects remain poorly understood and described (e.g., Chavez et al. 2007; Wanninkhof et al., 2015; Fennel et al., 2019). Uncertainties in carbon system patterns are particularly large in the Gulf of Mexico (GoM), a low-latitude semi-enclosed basin surrounded by the coasts of the southern United States and eastern Mexico (Fig. 1). The GoM encompasses diverse biogeochemical regimes, from the warm and oligotrophic open GoM, strongly influenced by the Loop Current and mesoscale eddies, to wide and productive continental shelves, influenced by river runoff- and wind-driven coastal currents (e.g., Dagg and Breed, 2003; Zavala-Hidalgo et al., 2006; Wang et al., 2013; Muller-Karger et al., 2015; Anglès et al., 2019). Therefore, multiple dynamics modulate the GoM carbon chemistry, which makes reducing uncertainties in these biogeochemical patterns a challenging task.

Most observational studies on carbon dynamics in the GoM have been conducted on the Louisiana-Texas shelf (e.g., Cai, 2003; Lohrenz et al., 2010, 2018; Guo et al., 2012; Cai et al., 2013; Huang et al., 2012; 2015; Hu et al., 2018). In this region, the Mississippi-Atchafalaya river system (MARS) has a strong influence, delivering a significant amount of freshwater, carbon, and nutrients, the latter fueling high biological production (Green et al., 2008; Lehrter et al., 2013). Enhanced primary production during spring and summer periods increases carbon uptake near the MARS delta, which results in decreased surface partial pressure of $\mathrm{CO}_{2}\left(p \mathrm{CO}_{2}\right)$ and increased ocean uptake of $\mathrm{CO}_{2}$ (Lohrenz et al., 2010, 2018; Guo et al., 2012; Huang et al., 2015; Hu et al., 2018). Subsequent sinking and remineralization of large amounts of organic carbon over the Louisiana-Texas shelf, concurrent with strong water column stratification, results in bottom acidification during the summer (Cai et al, 2011). The variability in carbon chemistry for other GoM areas has been less examined, but an increasing number of observations from dedicated research programs (e.g., Gulf of Mexico Ecosystem and Carbon Cycle, or GOMECC) and ship of opportunity (SOOP) programs are contributing to a reduction in the spatial and temporal data gaps. Robbins et al. (2014) derived estimates of sea-air $\mathrm{CO}_{2}$ fluxes over the entire GoM, concluding that the GoM basin is a $\mathrm{CO}_{2}$ sink. Recently, Robbins et al. (2018) described $p \mathrm{CO}_{2}$ patterns on the west Florida shelf, indicating that this region is mainly a $\mathrm{CO}_{2}$ source with significant spatial and seasonal variability.

Nevertheless, data gaps and observational constraints still limit our ability to infer carbon patterns in the ocean. Thus, regional ocean biogeochemical models that simulate carbon dynamics at multiple timescales are valuable tools to better understand the carbon system variability and its underlying drivers. In the GoM, several three-dimensional modeling studies addressing carbon cycle aspects have been conducted. Xue et al. (2016) used the Fennel biogeochemical model (Fennel et al. 2008; Fennel and Wilkin, 2009) to examine $p \mathrm{CO}_{2}$ and sea-air $\mathrm{CO}_{2}$ fluxes during 2005-2010. They reproduced observed spatiotemporal patterns across the GoM to some degree; however, some discrepancies between their model results and in situ observations are noted. For example, their model did not reproduce the decrease in surface $p \mathrm{CO}_{2}$ linked to high primary production over the MARS mixing zone (Huang et al., 2015), and spatially averaged values of model $p \mathrm{CO}_{2}$ were largely overestimated in the northern GoM during summer (by more than $100 \mu$ atm in several cases). In addition, the modeled sea-air $\mathrm{CO}_{2}$ flux in the northern GoM $\left(-0.32 \mathrm{~mol} \mathrm{~m}^{-2} \mathrm{yr}^{-1}\right)$ was about onethird of the flux derived by Huang et al. (2015) and Lohrenz et al. (2018), while the modeled flux for the deep Gulf $\left(-1.04 \mathrm{~mol} \mathrm{~m}^{-2} \mathrm{yr}^{-1}\right)$ was more than twice the flux derived by Robbins et al. (2014). In another modeling study, Laurent et al. (2017) examined near-bottom acidification driven by coastal eutrophication. Their model reproduced observed patterns in surface $p \mathrm{CO}_{2}$, sea-air $\mathrm{CO}_{2}$ fluxes, $\mathrm{pH}$, alkalinity, and dissolved inorganic carbon (DIC), but the model domain was limited to the Louisiana-Texas shelf.

Discrepancies between modeling results and observations, as well as the scarcity of biogeochemical modeling studies examining GoM-wide patterns, make additional modeling efforts necessary in order to reduce uncertainty in carbon patterns. In the present study, we use the outputs from a 15-component ocean biogeochemical model for the GoM to characterize the seasonal variability of the inorganic carbon system variables at the ocean surface, with a focus on aragonite saturation state $\left(\Omega_{\mathrm{Ar}}\right), p \mathrm{CO}_{2}$, as well as sea-air $\mathrm{CO}_{2}$ fluxes. This paper is structured such that we (1) describe the ocean biogeochemical model and dataset used for the study; (2) validate the model based on observations from a coastal buoy, the GOMECC-1 cruise, and SOOP; (3) describe surface inorganic carbon system variables; (4) describe sea-air $\mathrm{CO}_{2}$ fluxes in coastal and ocean domains; and (5) discuss the main model results in the context of previous observational and modeling studies.

\section{Model and data}

\subsection{Model}

The biogeochemical model is similar to the one described by Gomez et al. (2018), but with an additional carbon module that simulates dissolved inorganic carbon (DIC) and total alkalinity (TA). The carbon module is based on Laurent et al. (2017) formulations, and considers a carbon-tonitrogen ratio of 6.625 to link the carbon and nitrogen cycles. DIC is consumed by phytoplankton uptake, produced by zooplankton excretion and organic matter remineralization, and affected by sea-air $\mathrm{CO}_{2}$ fluxes. Changes in model TA are estimated using an explicit conservative expression for alkalinity (Wolf-Gladrow et al., 2007). Model $\mathrm{CO}_{2}$ fluxes are derived using the Wanninkhof (2014) bulk flux equation. Details of the carbon module can be found in Sect. S1 in 
Table 1. Mean $\mathrm{CO}_{2}$ flux derived from monthly model outputs during 2005-2014. Standard deviation is shown in parentheses. Negative flux implies ocean $\mathrm{CO}_{2}$ uptake, and positive flux $\mathrm{CO}_{2}$ outgassing (shown in bold). Shelf regions are depicted in Fig. 1.

\begin{tabular}{|c|c|c|c|c|c|c|}
\hline & GoM & Northern GoM shelf & West Florida shelf & Western GoM shelf & Yucatan shelf & Open GoM \\
\hline & \multicolumn{6}{|c|}{$\mathrm{mmolm}^{-2} \mathrm{~d}^{-1}$} \\
\hline Jan & $-4.03(1.91)$ & $-7.27(3.17)$ & $-4.74(1.83)$ & $-3.99(2.42)$ & $-2.63(0.96)$ & $-3.66(0.98)$ \\
\hline Feb & $-4.07(1.83)$ & $-7.08(2.54)$ & $-4.12(1.76)$ & $-4.01(2.39)$ & $-2.45(1.08)$ & $-3.87(1.15)$ \\
\hline Mar & $-3.70(1.78)$ & $-6.30(2.76)$ & $-3.38(1.56)$ & $-3.13(1.83)$ & $-1.80(1.04)$ & $-3.66(1.14)$ \\
\hline Apr & $-2.39(1.99)$ & $-5.19(3.36)$ & $-1.54(1.48)$ & $-1.33(1.71)$ & $-0.24(1.02)$ & $-2.45(1.21)$ \\
\hline May & $-0.35(1.58)$ & $-2.16(3.21)$ & $+0.32(1.20)$ & $+0.63(1.86)$ & $+1.05(1.12)$ & $-0.41(0.80)$ \\
\hline Jun & $+1.13(1.44)$ & $+0.11(2.80)$ & $+1.62(1.25)$ & $+1.87(1.93)$ & $+1.79(1.31)$ & $+1.11(0.91)$ \\
\hline Jul & $+1.50(1.27)$ & $+1.17(2.65)$ & $+1.84(1.12)$ & $+1.87(1.70)$ & $+1.97(1.28)$ & $+1.45(0.80)$ \\
\hline Aug & $+1.77(1.14)$ & $+1.83(2.37)$ & $+2.57(1.27)$ & $+1.55(1.16)$ & $+1.99(1.24)$ & $+1.65(0.70)$ \\
\hline Sep & $+1.92(1.23)$ & $+3.22(2.17)$ & $+2.28(1.16)$ & $+1.80(1.36)$ & +1.79 (1.19) & $+1.72(0.85)$ \\
\hline Oct & $+1.04(1.11)$ & $+0.72(1.68)$ & $+1.15(1.10)$ & $+1.40(0.95)$ & $+1.21(1.17)$ & $+1.06(0.94)$ \\
\hline Nov & $-1.37(1.27)$ & $-3.40(1.88)$ & $-2.00(1.42)$ & $-0.85(0.95)$ & $-0.76(0.90)$ & $-1.08(0.77)$ \\
\hline Dec & $-3.07(1.71)$ & $-6.37(2.40)$ & $-3.68(1.78)$ & $-2.94(1.88)$ & $-1.91(0.82)$ & $-2.66(0.86)$ \\
\hline \multirow[t]{2}{*}{ Annual } & $-0.97(2.78)$ & $-2.56(4.52)$ & $-0.81(2.98)$ & $-0.60(3.41)$ & $0.00(2.05)$ & $-0.90(2.37)$ \\
\hline & \multicolumn{6}{|c|}{$\mathrm{molm}^{-2} \mathrm{yr}^{-1}$} \\
\hline \multirow[t]{2}{*}{ Annual } & $-0.35(1.01)$ & $-0.93(1.65)$ & $-0.30(1.09)$ & $-0.22(1.24)$ & $0.00(0.75)$ & $-0.33(0.87)$ \\
\hline & \multicolumn{6}{|c|}{$\mathrm{gCm}^{-2} \mathrm{yr}^{-1}$} \\
\hline Annual & $-4.2(12.1)$ & $-11.2(19.8)$ & $-3.6(13.1)$ & $-2.6(14.9)$ & $0.0(9.0)$ & $-4.0(10.4)$ \\
\hline
\end{tabular}

Supplement. A description of the model's nitrogen and silica cycle components is found in Gomez et al. (2018).

The coupled ocean circulation-biogeochemical model was implemented on the Regional Ocean Model System (ROMS; Shchepetkin and McWilliams, 2005). The model domain extends over the entire Gulf of Mexico (Fig. 1), with a horizontal resolution of $\sim 8 \mathrm{~km}$, and 37 sigma-coordinate (bathymetry-following) vertical levels. A third-order upstream scheme and a fourth-order Akima scheme were used for horizontal and vertical momentum, respectively. A multidimensional positive definitive advection transport algorithm (MPDATA) was used for tracer advection. Vertical turbulence was resolved by the Mellor and Yamada 2.5-level closure scheme. Initial and open-boundary conditions were derived from a $25 \mathrm{~km}$ resolution Modular Ocean Model for the Atlantic Ocean (Liu et al., 2015), which includes TOPAZ (Tracers of Ocean Phytoplankton with Allometric Zooplankton) as a biogeochemical model (Dunne et al., 2013). The model was forced with surface fluxes of momentum, heat, and freshwater from the European Center for Medium Range Weather Forecast reanalysis product (ERA-Interim; Dee et al., 2011), as well as 54 river sources of freshwater, nutrients, TA, and DIC (http://waterdata.usgs.gov/nwis/qw, last access:23 September 2018; Aulenbach et al., 2007; He et al., 2011; Martinez-Lopez and Zavala-Hidalgo, 2009; MunozSalinas and Castillo, 2015; Stets et al., 2014). Monthly TA series for the MARS were derived from observations col- lected at the USGS stations 7373420 and 7381600 . Following Stet and Striegl (2012), riverine DIC concentrations were calculated from observations of $\mathrm{pH}$, TA, and temperature. Observational gaps in the Atchafalaya series were filled out using linear equations linking chemical properties at the Atchafalaya station to those at the Mississippi station (Sect. S2). For rivers other than the MARS, we used mean climatological DIC and TA values, as the availability of data for these rivers was insufficient to generate monthly series over the entire study period. The partial pressure of atmospheric $\mathrm{CO}_{2}$ was prescribed as a continuous nonlinear function, derived from the Mauna Loa monthly $\mathrm{CO}_{2}$ time series (https://www.esrl.noaa.gov/gmd/ccgg/trends/, last access: 16 August 2018) using similar curve-fitting method that Thoning et al. (1989; Sect. S3).

The ocean biogeochemical model in Gomez et al. (2018) was spun-up for 40 years. In the present study, an additional 9-year spin-up for the carbon system components was completed, using the basin-model boundary conditions, ERA surface forcing, and river runoff from 1981-1983. After completing the spin-up, the model was run continuously from January 1981 to November 2014, with averaged outputs saved at a monthly frequency. DIC and TA, in conjunction with temperature and salinity, were used to derive the full set of inorganic carbon system variables, including $p \mathrm{CO}_{2}$ and $\Omega_{\mathrm{Ar}}$. The calculations were performed using the Mat$\mathrm{Lab}$ version of the CO2SYS program for $\mathrm{CO}_{2}$ System Cal- 


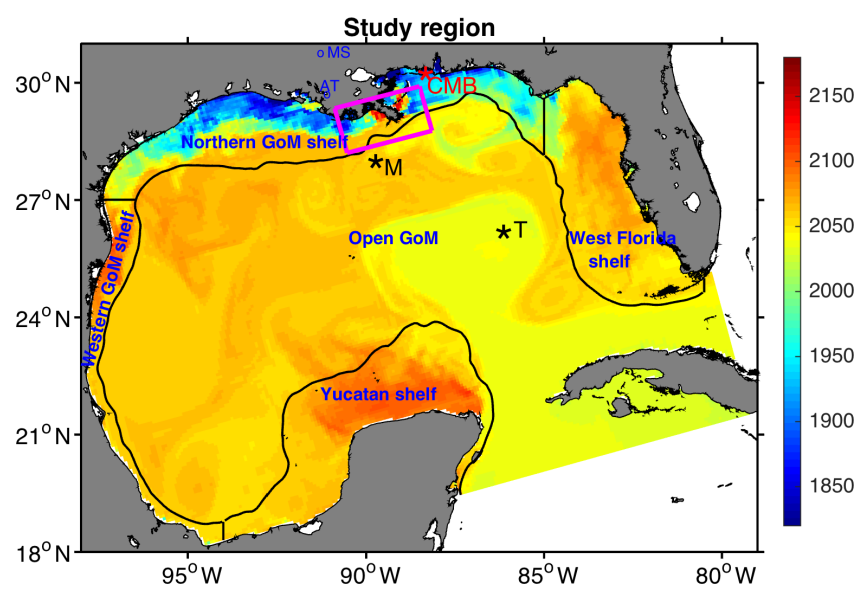

Figure 1. Model snapshot of surface dissolved inorganic carbon $\left(\mathrm{mmolm}^{-3}\right)$ during 1 May 2009. Regions used to describe model results are the western GoM shelf, the northern GoM shelf, the west Florida shelf, the Yucatan shelf, and open GoM. Shelf regions are delimited offshore by the $200 \mathrm{~m}$ isobath. Black stars depict the location of two GOMECC stations at the Mississippi (M) and Tampa (T) lines used to validate the model. Red star depicts the location of the Coastal Mississippi Buoy (CMB). Blue circles indicate USGS stations 7373420 and 7381600 at the Mississippi (MS) and Atchafalaya (AT) rivers, respectively. The magenta polygon demarks the region near the Mississippi Delta used to derive patterns in Fig. 7.

culations (van Heuven et al., 2011), considering the total pH scale, the carbonic acid dissociation constants of Mehrbach et al. (1973) as refitted by Dickson and Millero (1987), the boric acid dissociation constant of Dickson (1990a), and the $\mathrm{KSO}_{4}$ dissociation constant of Dickson (1990b).

For the present study, we focused on describing seasonal patterns in surface $\Omega_{\mathrm{Ar}}$, surface $p \mathrm{CO}_{2}$, and sea-air $\mathrm{CO}_{2}$ flux during 2005-2014 (i.e., the last 10 years of the model run). $\Omega_{\mathrm{Ar}}$ represents the degree of saturation of calcium carbonate $\left(\mathrm{CaCO}_{3}\right)$ phase aragonite, with $\Omega_{\mathrm{Ar}}$ values less than 1 indicating undersaturation (aragonite is thermodynamically unstable, which favors dissolution), and $\Omega_{\mathrm{Ar}}$ values greater than 1 indicating oversaturation (seawater favors aragonite precipitation). $\Omega_{\mathrm{Ar}}$ is defined as

$\Omega_{\mathrm{Ar}}=\left[\mathrm{Ca}^{2+}\right]\left[\mathrm{CO}_{3}^{2-}\right]\left(K_{\mathrm{Ar}}^{\prime}\right)^{-1}$,

where $\left[\mathrm{Ca}^{2+}\right]$ is total calcium concentration, which is a function of salinity, $\left[\mathrm{CO}_{3}^{2-}\right]$ is total carbonate ion concentration, which is derived from the simulated DIC and TA, and $K_{\mathrm{Ar}}^{\prime}$ is the apparent solubility product of the $\mathrm{CaCO}_{3}$ phase aragonite in seawater, which increases with pressure and salinity, and decreases with temperature (Mucci, 1983; Millero, 1995). At a given pressure, temperature, and salinity, changes in $\Omega_{\mathrm{Ar}}$ mainly depend on $\left[\mathrm{CO}_{3}^{2-}\right]$, and are positively related to changes in the TA : DIC ratio (Wang et al., 2013).
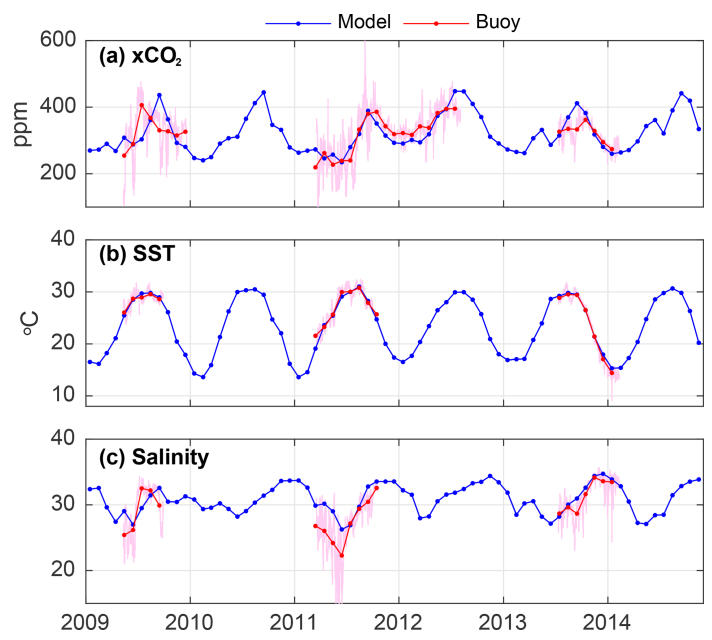

Figure 2. Time series of mole fraction of $\mathrm{CO}_{2}\left(x \mathrm{CO}_{2}\right)$, SST, and surface salinity derived from a surface mooring (Coastal Mississippi Buoy) and model outputs at $30^{\circ} \mathrm{N}$ and $88.6^{\circ} \mathrm{W}$ (location depicted as red star in Fig. 1). Simulated and observed monthly averages are shown as blue and red lines, respectively. Buoy data ( $6 \mathrm{~h}$ interval) are depicted in magenta.

\subsection{Data}

Surface measurements of mole fraction of $\mathrm{CO}_{2}\left(x \mathrm{CO}_{2}\right)$, temperature, and salinity from the Central Gulf of Mexico Ocean Observing System (Coastal Mississippi Buoy) at $30^{\circ} \mathrm{N}$ and $88.6^{\circ} \mathrm{W}$ (Sutton et al., 2014; Fig. 1) were retrieved from the NOAA National Center for Environmental Information (https://www.nodc.noaa.gov, last access: 4 March 2019). Vertical profiles for DIC, TA, temperature, and salinity off Tampa (Florida) and Louisiana were derived from measurements collected during the GOMECC-1 cruise; Wang et al., 2013), retrieved from NOAA-AOML (http://www. aoml.noaa.gov/ocd/gcc/GOMECC1, last access: 4 March 2019). Surface $p \mathrm{CO}_{2}$ data were obtained from underway measurements collected onboard research cruises and multiple ships of opportunity, and compiled by Barbero et al. (in preparation). The $p \mathrm{CO}_{2} \_\mathrm{GoM} \_2018$ dataset, which contains more than 457000 measurements in the GoM during 20052014 (Fig. S5), is available as a data package from NCEL.

\section{Model-data comparison}

We used data from the Coastal Mississippi Buoy to evaluate the model's ability to reproduce coastal patterns in $x \mathrm{CO}_{2}$, temperature, and salinity in the northern GoM shelf (Fig. 2). Overall, simulated temporal surface patterns agreed with observations, especially considering that the buoy is located within a region highly impacted by river runoff, strong crossshore gradients, and high variability in salinity, DIC, and TA. We can expect therefore that relatively small changes in river plume location (such as those derived from Mobile Bay and 

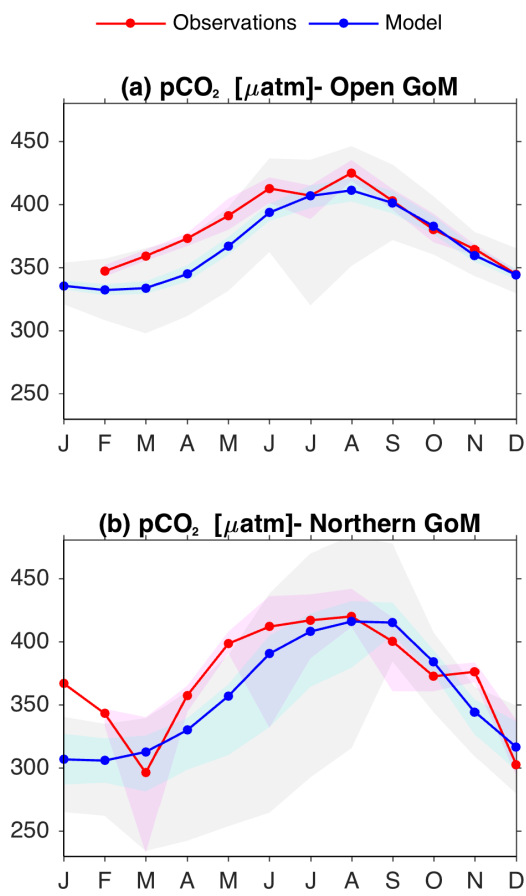

Figure 3. Mean monthly patterns for the observed (red lines) and simulated (blue lines) surface $p \mathrm{CO}_{2}$ over the (a) open GoM and (b) northern GoM regions (shown in Fig. 1). Light pink and cyan shading depict the observed and modeled interquartile interval, respectively. Gray shading depict the model's 5-95\% percentile interval. Observations are from ships of opportunity and research cruises conducted during 2005-2014 (ship tracks are shown in Fig. S4.1).

the Mississippi River) can significantly impact salinity and $x \mathrm{CO}_{2}$, making the exact reproduction of observed buoy patterns challenging. The best match between simulated and observed $x \mathrm{CO}_{2}$ was during 2011-2012, where $x \mathrm{CO}_{2}$ ranged from about $230 \mathrm{ppm}$ in spring to more than $400 \mathrm{ppm}$ in fall.

The $p \mathrm{CO}_{2} \mathrm{GoM}$ 2018 dataset was used to compare climatological seasonal patterns in $p \mathrm{CO}_{2}$ (Fig. 3). Overall, simulated and observed $p \mathrm{CO}_{2}$ patterns were in good agreement. In the open GoM region, there was a close match between model and observed patterns in July-December, with a relatively small model underestimation ( $\sim 10$ to $20 \mu$ atm) during February-June (Fig. 3a). In the northern GoM, the largest disagreement was observed in January-February (Fig. 3b), but this difference is most likely due to the reduced number of observations during winter in the $p \mathrm{CO}_{2} \mathrm{GoM} \_2018$ dataset (Fig. S6 in the Supplement). Indeed, January observations came from only one cruise, which largely increases observational uncertainty. A spatial visualization of the $p \mathrm{CO}_{2} \mathrm{GoM} 2018$ observations and model outputs is presented for each calendar month in Fig. S6. The main spatial features were well reproduced by the model, including the $p \mathrm{CO}_{2}$ minimum near the MARS region, and the large seasonal amplitude in the western Florida shelf.
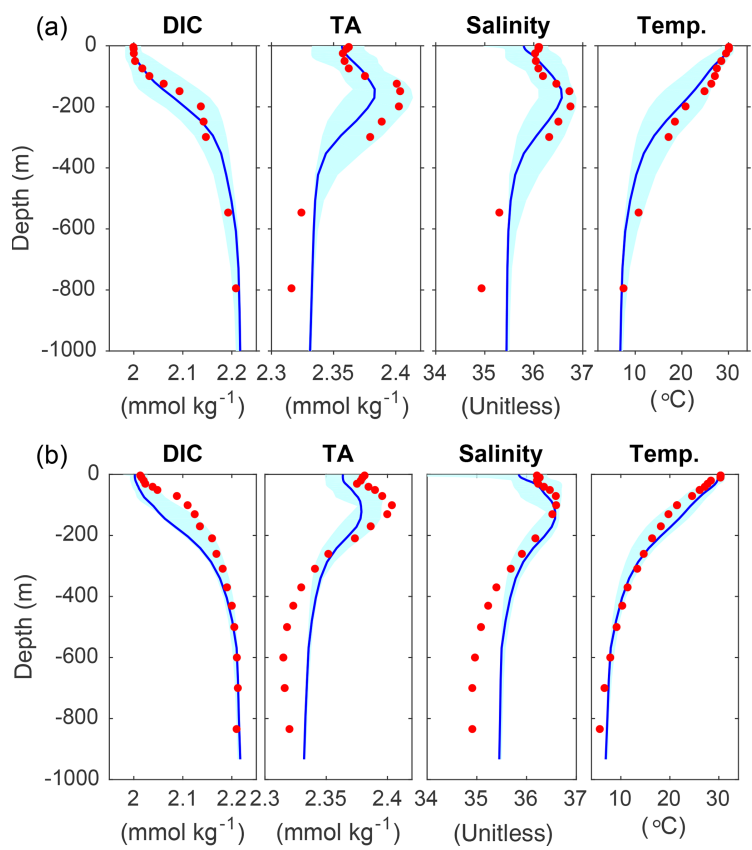

Figure 4. Comparison between profiles of dissolved inorganic carbon (DIC), total alkalinity (TA), salinity, and temperature from monthly model outputs (blue lines) and GOMECC-1 data (red dots) for the most oceanic station on the (a) Tampa and (b) Mississippi lines (station locations are shown in Fig. 1 as black stars). The range of the model's variables for June-August during 2000-2014 is also shown as cyan shading.

We also compared vertical patterns in DIC, TA, temperature, and salinity derived from the model, with vertical profiles from the GOMECC-1 cruise (Fig. 4). The model reproduced the main patterns in DIC, TA, salinity, and temperature well, especially off Tampa. Monthly averaged model DIC and TA were underestimated in the upper $200 \mathrm{~m}$ off Louisiana (Mississippi line), with the bias ranging from around 5 to $90 \mu \mathrm{mol} \mathrm{kg}-1$ for DIC and 5 to $40 \mu \mathrm{mol} \mathrm{kg}$ for TA, but the observations were within or close to the simulated variable's ranges during June-August 2000-2014. These model-observation differences could be partly due to misrepresentation of cross-shore transport in a region strongly influenced by the Mississippi River runoff. Also, TA and salinity were overestimated below $400 \mathrm{~m}$ at both stations by around $25 \mu \mathrm{mol} \mathrm{kg} \mathrm{kg}^{-1}$ and 0.3 , respectively, but this bias had a limited impact on the surface properties and fluxes examined (see following sections). Overall, our comparisons between model outputs and observations indicated that the model faithfully reproduced relevant inorganic carbon system features and patterns, and therefore was suitable for characterizing seasonal and spatial patterns of $p \mathrm{CO}_{2}$ and $\Omega_{\mathrm{Ar}}$ for the 2005-2014 study period. 


\section{Surface $p \mathrm{CO}_{2}$ and $\Omega_{\mathrm{Ar}}$ seasonality}

Model-derived patterns for surface $p \mathrm{CO}_{2}$ showed significant seasonal variability across the GoM (Fig. 5). Minimum and maximum $p \mathrm{CO}_{2}$ values were generally observed during winter and summer seasons, respectively, although large spatial differences were observed among the shelf regions. A notable model feature was observed in the central part of the northern GoM near the MARS delta, where $p \mathrm{CO}_{2}$ displayed low values year-round $(<350 \mu \mathrm{tm})$, with a seasonal minimum in spring. Other coastal regions less impacted by riverine discharge displayed much higher $p \mathrm{CO}_{2}$ values during spring and summer (Fig. 5b and c). The continental shelf with the highest seasonally averaged $p \mathrm{CO}_{2}$ was the west Florida shelf, where $p \mathrm{CO}_{2}$ reached values greater than $450 \mu$ atm during the summer. Seasonality in modeled $p \mathrm{CO}_{2}$ was strongly modulated by sea surface temperature (SST), such that the annual amplitude for these two variables displayed very consistent spatial patterns (Figs. 6a, b and S7). The largest annual signal for $p \mathrm{CO}_{2}$ and SST was within the northern GoM shelf and west Florida shelf, and the smallest was in the Loop Current region. Monthly time series of modeled $p \mathrm{CO}_{2}$ and SST were strongly correlated in all regions except near the MARS delta (Fig. 6c).

The low $p \mathrm{CO}_{2}$-SST correlation near the MARS delta can be explained by the role that river runoff and enhanced primary production play as drivers of carbon system variability. This was evident in the variability of modeled $p \mathrm{CO}_{2}$ along the salinity gradient linked to the Mississippi River plume (Fig. 7). The simulated surface $p \mathrm{CO}_{2}$ patterns during spring and summer displayed a marked increase from middle to low salinities (Fig. 7a and d), which was also associated with an increase in DIC (Fig. 7b and e). The minimum $p \mathrm{CO}_{2}$ values were about $285 \mu \mathrm{atm}$ in spring and $320 \mu \mathrm{atm}$ in summer, at salinities close to 30 and 27 , respectively. To identify the drivers of DIC variability along the salinity gradient, we displayed the simulated budget terms for surface DIC as a function of salinity. These budget terms correspond to the sea-air $\mathrm{CO}_{2}$ flux (Sea-air), the combined effect of advection and mixing ( $\mathrm{Adv}+\mathrm{Mix}$ ), and the net community production (NCP), the latter representing the difference between primary production and respiration (i.e., biologically driven changes in DIC). The derived patterns for spring-summer showed model DIC losses at middle salinities mainly driven by NCP, indicative of a biologically induced drawdown of $p \mathrm{CO}_{2}$. During fall (Fig. $7 \mathrm{~g}-\mathrm{i}$ ), as well as winter (not shown), NCP was much smaller than during spring-summer, and DIC was mainly controlled by sea-air exchange and advection plus mixing processes. As a consequence, model surface $p \mathrm{CO}_{2}$ did not show a middle salinity minimum linked to phytoplankton uptake.

The simulated patterns for surface $\Omega_{\mathrm{Ar}}$ (Fig. 8) revealed a significant meridional gradient from fall to spring, with minimum values in the inner shelves from northern GoM and west Florida (2.5-3.6), and maximum values over the
Loop Current and west of the Yucatan Peninsula (3.9-4.1). During summer, the simulated surface $\Omega_{\text {Ar }}$ reached its maximum near the MARS delta $(>4.5)$, while relatively weak $\Omega_{\text {Ar }}$ gradients were observed across the open GoM region. Surface $\Omega_{\text {Ar }}$ generally displayed maximum values in summer and minimum in winter, though always well above the saturation threshold of 1 . This seasonal variation in surface $\Omega_{\text {Ar }}$ was strongly correlated to changes in the TA:DIC ratio and SST (Fig. 9a and b). Although the seasonal patterns for $\Omega_{\mathrm{Ar}}$ and $p \mathrm{CO}_{2}$ displayed a similar phase (maximum in summer, minimum in winter), the spatial variability of these two variables was opposite. This was most evident during spring-summer (Figs. 5b and $\mathrm{c}$ and $8 \mathrm{~b}$ and c), when the highest $\Omega_{\mathrm{Ar}}$ and lowest $p \mathrm{CO}_{2}$ values were co-located near the MARS delta, and the lowest $\Omega_{\mathrm{Ar}}$ and highest $p \mathrm{CO}_{2}$ values were in the west Florida shelf and the western part of the northern GoM shelf. The annual amplitude of $\Omega_{\mathrm{Ar}}$ displayed a similar pattern to the annual amplitude of surface salinity, especially over the northern GoM, indicating a strong influence of river discharge on $\Omega_{\mathrm{Ar}}$ seasonality (Figs. S8 and S9). The correlation between $\Omega_{\mathrm{Ar}}$ and salinity showed negative values over the northern GoM and eastern part of the open GoM (Fig. 9c). This pattern was consistent with enhanced biological uptake of DIC promoted by MARS's nutrient inputs, and the positive salinity impact on aragonite solubility.

To better describe the impact of SST in the simulated $p \mathrm{CO}_{2}$ and $\Omega_{\mathrm{Ar}}$ variability, we calculated average monthly climatologies for temperature-normalized $p \mathrm{CO}_{2}$ and $\Omega_{\mathrm{Ar}}$ at $25^{\circ} \mathrm{C}$ ( $p \mathrm{CO}_{2 \_ \text {at25 }}$ and $\Omega_{\mathrm{Ar} \_a t 25}$, respectively), and compared them with non-normalized patterns in five regions designated as the northern GoM shelf, west Florida shelf, western GoM shelf, Yucatan shelf, and open GoM (Fig. 10a-d; regions depicted in Fig. 1). Surface $p \mathrm{CO}_{2 \_a t 25}$ and $\Omega_{\mathrm{Ar} \_a t 25}$ were calculated with the CO2SYS program, using the simulated DIC, $\mathrm{TA}$, and salinity patterns, and $25^{\circ} \mathrm{C}$ (which is close to the average SST over the GoM basin). The strong influence of SST on model $p \mathrm{CO}_{2}$ was evident when we compared the monthly climatologies for $p \mathrm{CO}_{2}$ and $p \mathrm{CO}_{2 \_ \text {at25 }}$ (Fig. 10a and b). Surface $p \mathrm{CO}_{2 \_ \text {at25 }}$ displayed much weaker annual variation than surface $p \mathrm{CO}_{2}$, and the timing for the seasonal maxima and minima largely differed. Indeed, surface $p \mathrm{CO}_{2 \_ \text {at25 }}$ peaked during January-February in the northern GoM, during March in the west Florida and western GoM regions, and during February in the open GoM regions, i.e., when $p \mathrm{CO}_{2}$ was at or near its lowest levels. The comparison between $\Omega_{\mathrm{Ar}}$ and $\Omega_{\mathrm{Ar} \_a t 25}$ also revealed significant temperature influence on model $\Omega_{\text {Ar }}$ seasonality (Fig. 10c and d). Specifically, SST amplified the annual variation in $\Omega_{\mathrm{Ar}}$, while having a relatively weak impact on the $\Omega_{\mathrm{Ar}}$ seasonal phase. Both $\Omega_{\mathrm{Ar}}$ and $\Omega_{\mathrm{Ar} \_ \text {at25 }}$ were inversely related to $p \mathrm{CO}_{2 \_ \text {at25 }}$, reflecting the variables' dependency on DIC and TA $\left(\Omega_{\mathrm{Ar}}\right.$ increases with TA and decreases with DIC, while $p \mathrm{CO}_{2 \_ \text {at25 }}$ has the opposite pattern). 
(a) $\mathrm{pCO}_{2}[\mu \mathrm{atm}]-\mathrm{DJF}$

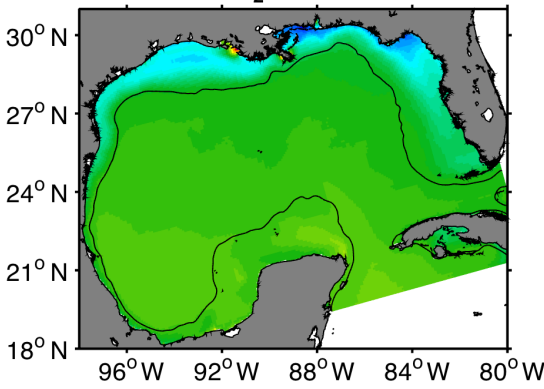

(c) $\mathrm{pCO}_{2}[\mu \mathrm{atm}]-\mathrm{JJA}$

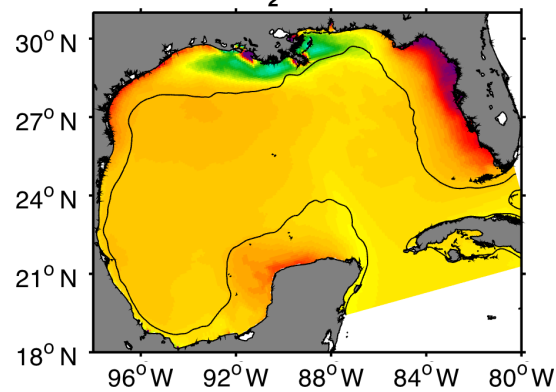

(b) $\mathrm{pCO}_{2}[\mu \mathrm{atm}]-$ MAM

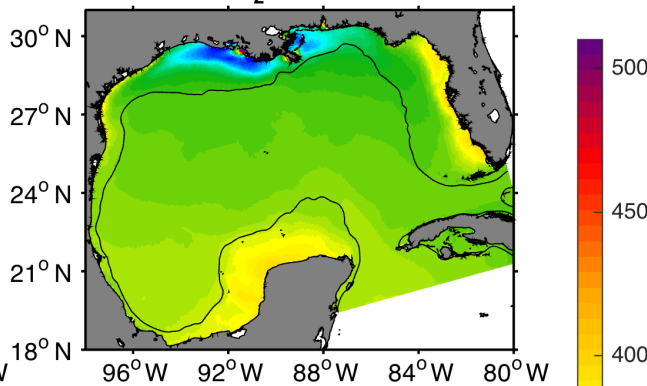

(d) $\mathrm{pCO}_{2}[\mu \mathrm{atm}]-\mathrm{SON}$

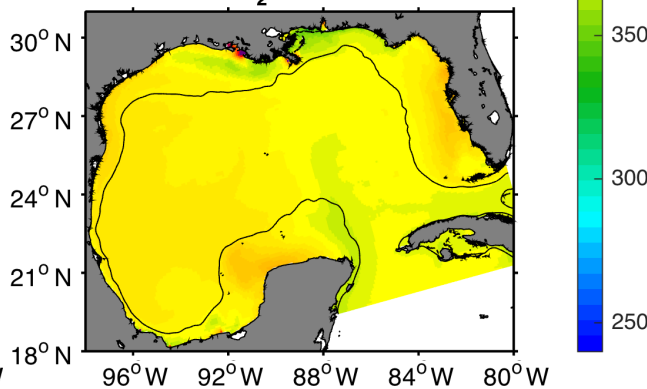

Figure 5. Mean model surface $p \mathrm{CO}_{2}(u \mathrm{~atm})$ in winter (DJF), spring (MAM), summer (JJA), and fall (SON) during 2005-2014. The black contour depicts the $200 \mathrm{~m}$ isobath.

Simulated climatological patterns for DIC and TA (Figs. 10e, f; S10 and S11) allowed us to investigate the importance of DIC and TA as drivers of $p \mathrm{CO}_{2 \_ \text {at25 }}$ and $\Omega_{\mathrm{Ar} \_ \text {at25 }}$ seasonality. In the open GoM, west Florida, and western GoM regions, changes in TA were small, so the seasonal pattern in $\Omega_{\text {Ar }}$ was mainly due to DIC changes. Maximum surface DIC values during late winter and early spring can be linked to increased uptake of atmospheric $\mathrm{CO}_{2}$ (see Sect. 5) and enhanced vertical mixing, promoted by surface cooling and winds. Alternatively, both DIC and TA played an important role modulating $\Omega_{\mathrm{Ar}}$ seasonality in northern GoM and Yucatan Peninsula shelves. In the former, the annual variation of DIC and TA was strongly modulated by river runoff, which is mostly associated with the MARS. Whether the MARS dilutes ocean DIC and TA depends on the season. Alkalinity in the Atchafalaya River was lower than the open GoM alkalinity year-round, whereas Mississippi alkalinity was lower than open GoM alkalinity during DecemberJune and greater the rest of the year (Fig. S3a). The DIC of the Atchafalaya was smaller than open GoM DIC during December-May and greater from June to November, while Mississippi DIC was greater or equal to the open GoM DIC year-round (Fig. S3b). We did not prescribe time-evolving DIC and TA for rivers other than the Mississippi River, but according to USGS records most of these other rivers have lower long-term average DIC and TA than the oceanic values. Consequently, low TA values in the northern GoM during spring can be explained by a dilution effect, linked to maximum river discharge in the northern GoM during winter- spring. Low DIC values during spring-summer can be associated with high biological uptake, promoted by riverine nutrients and enhanced solar radiation, along with dilution (especially in spring) linked to high discharge of low DIC waters delivered by major river inputs, like the Atchafalaya River and Mobile Bay. This is not the case for the Mississippi River, which had DIC values greater than the open GoM. Along the Yucatan Peninsula, simulated surface DIC and TA patterns showed maximum values in summer and minimum values in winter. Coastal upwelling of DIC- and TA-rich waters along the northern Yucatan Peninsula coast, reflected in a significant correlation between easterly (alongshore) winds and both DIC and TA ( $r=0.65$ and 0.60 , respectively, with wind leading by 1 month; Fig. S12a), influenced this seasonal pattern. The similar annual amplitude and phase for DIC and $\mathrm{TA}$, as well as high TA values year-round, caused a relatively weak seasonal variability for $p \mathrm{CO}_{2 \_ \text {at25 }}$ and $\Omega_{\mathrm{Ar} \_ \text {at25 }}$ on the Yucatan shelf. Still, a significant correlation between easterly winds and surface $p \mathrm{CO}_{2}$ at25 $(r=0.55)$ was found in the northern Yucatan coast, with $p \mathrm{CO}_{2 \_ \text {at25 }}$ usually peaking during spring (Fig. S12b).

\section{Sea-air $\mathrm{CO}_{2}$ fluxes}

Seasonal changes in surface model $p \mathrm{CO}_{2}$, mainly driven by SST changes (Fig 6c), determined strong seasonal variability in simulated sea-air $\mathrm{CO}_{2}$ fluxes. As a consequence, the $\mathrm{GoM}$ becomes a $\mathrm{CO}_{2}$ sink in winter-spring and a $\mathrm{CO}_{2}$ 

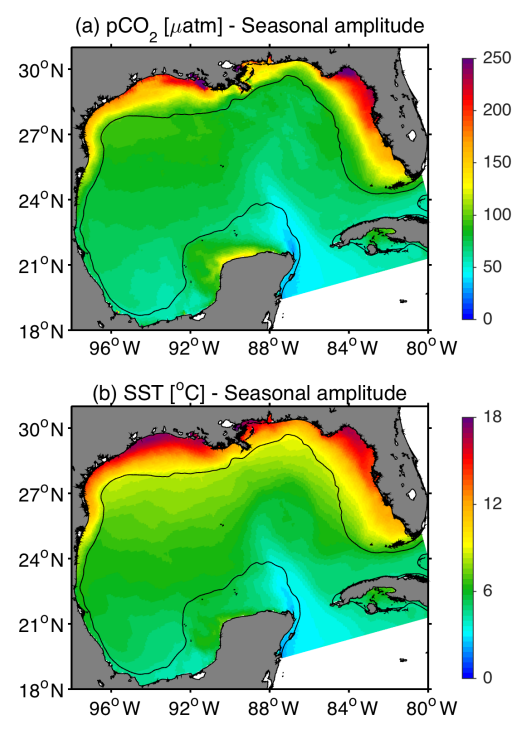

(c) $\mathrm{r}[\mathrm{pCO}-\mathrm{SST}]$

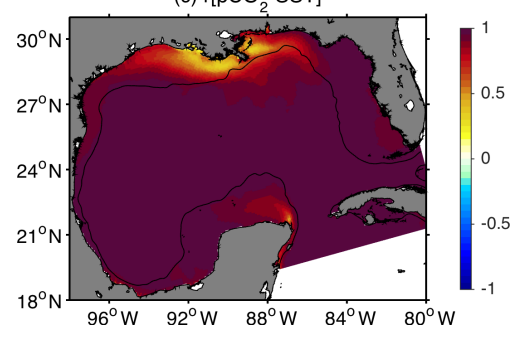

Figure 6. (a, b) Seasonal amplitude patterns for model surface $p \mathrm{CO}_{2}$ and SST. The seasonal amplitude is the difference between the maximum and minimum values from monthly climatologies at each grid point (c) Correlation between surface model $p \mathrm{CO}_{2}$ and SST. Black contour depicts the $200 \mathrm{~m}$ isobath.

source in summer-fall (Fig. 11a-d). An exception to this pattern occurred close to the MARS delta, which is predominantly a $\mathrm{CO}_{2}$ sink year-round. In this region, the $p \mathrm{CO}_{2}$ drop induced by phytoplankton uptake during spring-summer (Fig. 7a and d) determined maximum uptake of atmospheric $\mathrm{CO}_{2}$ at middle salinities (seen in the sea-air exchange term in Fig. $7 \mathrm{c}$ and $\mathrm{f}$ ). The greatest model $\mathrm{CO}_{2}$ uptake, above $7 \mathrm{mmol} \mathrm{m}^{-2} \mathrm{~d}^{-1}$, occurred over the northern GoM shelf during winter, as this region experiences the lowest surface $p \mathrm{CO}_{2}$ values induced by the coldest winter conditions in the region (Fig. S7). The greatest model $\mathrm{CO}_{2}$ outgassing, disregarding local peaks near major river mouths like the Mississippi River, was observed on the west Florida shelf (northern inner shelf in particular), southern Texas shelf (northern and western GoM), and western Yucatan Peninsula during the summer, ranging from $\sim 2$ to $3 \mathrm{mmol} \mathrm{m}^{-2} \mathrm{~d}^{-1}$ (Fig. 11c). Maximum SST values characterized summer conditions in these regions (Fig. S7). The annual mean pattern showed modeled $\mathrm{CO}_{2}$ uptake ranging from -4 to $-1 \mathrm{mmolm}^{-2} \mathrm{~d}^{-1}$ in the northern GoM, and from -2 to $0 \mathrm{mmolm}^{-2} \mathrm{~d}^{-1}$ elsewhere (Fig. 11e). In addition, the pattern revealed areas where $\mathrm{CO}_{2}$ outgassing occurred near the Mississippi River,
Atchafalaya River, and Mobile Bay mouths, on the western Yucatan Peninsula, and nearshore over the west Florida shelf (Fig. 11e).

The estimated monthly patterns for modeled sea-air $\mathrm{CO}_{2}$ flux revealed prevailing $\mathrm{CO}_{2}$ outgassing during MayOctober in west Florida, western GoM, and Yucatan Peninsula, and June-October in the northern and open GoM (Fig. 11f; Table 1). The timing for the maximum $\mathrm{CO}_{2}$ outgassing was June-July in the western GoM, August in west Florida and Yucatan, and September in the northern and open GoM. The timing for the maximum $\mathrm{CO}_{2}$ uptake was January in the northern GoM, west Florida, and Yucatan Peninsula, and February in the western and open GoM. The model annual flux for the northern GoM, west Florida, western GoM, Yucatan, and open GoM are $-2.56,-0.81,-0.60$, 0.0 , and $-0.90 \mathrm{mmolm}^{-2} \mathrm{~d}^{-1}$, respectively. For the entire GoM basin, the simulated average annual flux and standard deviation was -0.97 and $2.78 \mathrm{mmol} \mathrm{m}^{-2} \mathrm{~d}^{-1}(-0.35$ and $\left.1.01 \mathrm{~mol} \mathrm{~m}^{-2} \mathrm{yr}^{-1}\right)$, respectively. Integrated across the entire model domain, the resulting flux was $-7.0 \mathrm{Tg} \mathrm{C} \mathrm{yr}^{-1}$.

\section{Discussion}

\subsection{Simulated carbon patterns}

Characterization of historical carbon system patterns are needed to advance our understanding of carbon dynamics, as well as to identify coastal ecosystem susceptibility to ocean acidification (Wanninkhof et al., 2015). Previous studies have described to some degree surface $p \mathrm{CO}_{2}$ seasonality within the GoM (e.g., Lohrenz et al., 2010, 2018; Robbins et al., 2018), but less has been done to describe seasonal patterns for other inorganic carbon system variables. In the present study, we focused our analysis on the seasonal cycles of surface $p \mathrm{CO}_{2}$ and $\Omega_{\mathrm{Ar}}$, but seasonal patterns of surface DIC and TA were also reported. We used a similar model to the one configured by Gomez et al. (2018) for the GoM, with an extra carbon module to simulate carbon dynamics, following model formulations described by Laurent et al. (2017). As shown in Sect. 3, the model simulated the main surface spatiotemporal patterns for the inorganic carbon system well. Compared to a previous basin-wide modeling effort (Xue et al., 2016), our model shows significantly less seasonal biases in surface $p \mathrm{CO}_{2}$, with relatively minor $p \mathrm{CO}_{2}$ underestimation during spring $(<20 \mu \mathrm{atm})$. Further model refinements could be required for improving the representation of carbon system dynamics. These include incorporating additional model components and processes, like dissolution and precipitation of calcium carbonate that will affect TA, improving the representation of land-ocean biogeochemical fluxes (e.g., prescribing time evolving TA and DIC for rivers other than the MARS), and increasing the model's horizontal resolution to resolve sub-mesoscale dynamics. Our current model configuration represents an important advance in the 

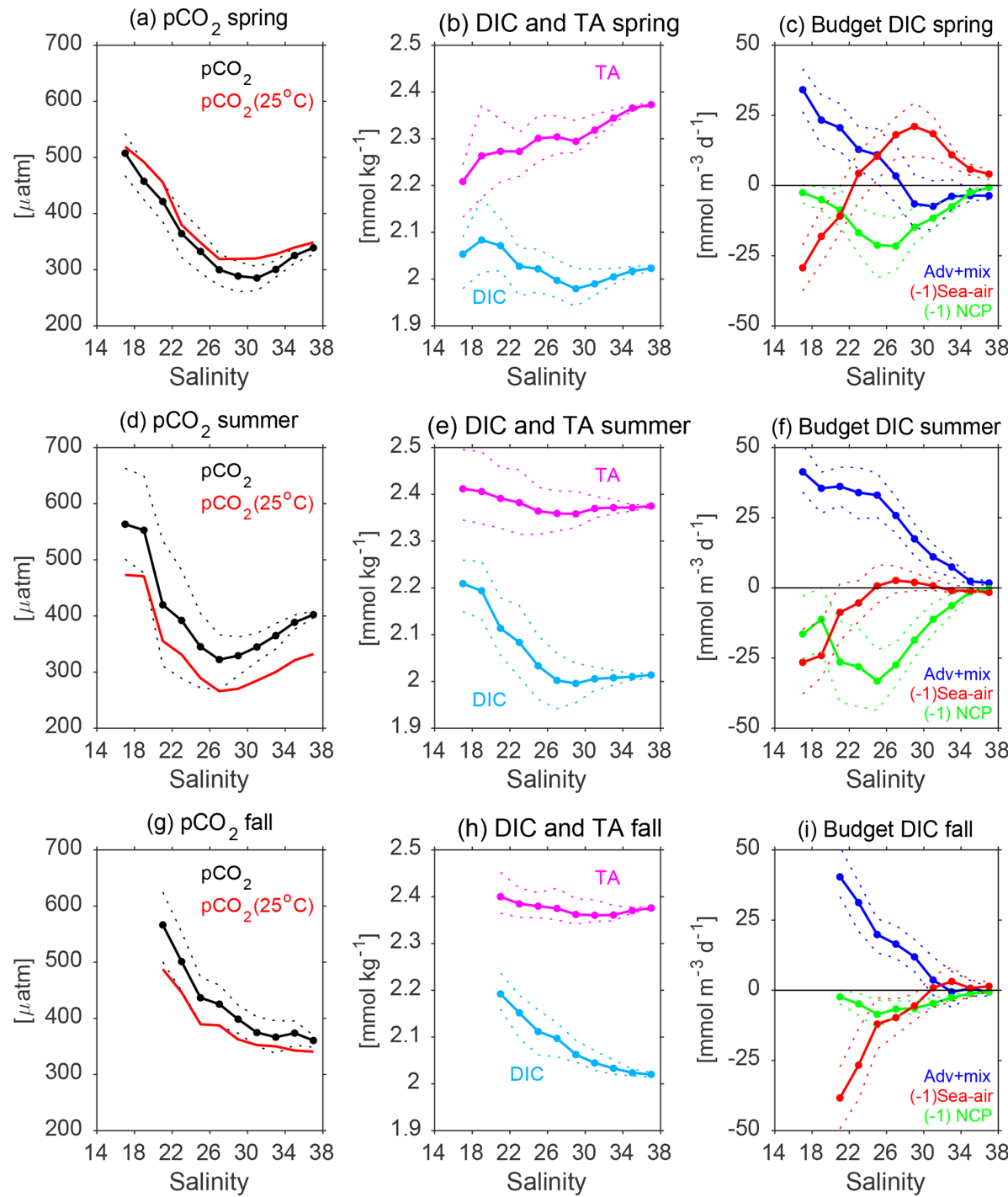

Figure 7. Mean patterns of simulated surface variables as a function of salinity near the Mississippi River (magenta polygon in Fig. 1) during spring (a-c), summer (d-f), and fall $(\mathbf{g}-\mathbf{i})$ : $(\mathbf{a}, \mathbf{d}, \mathbf{g}) \quad p \mathrm{CO}_{2}$ and $p \mathrm{CO}_{2}$ normalized to $25^{\circ} \mathrm{C}$; (b, e, $\left.\mathbf{h}\right)$ dissolved inorganic carbon $(\mathrm{DIC})$ and total alkalinity (TA); (c, f, i) budget terms for DIC: advection plus mixing (Adv + Mix), sea-air $\mathrm{CO}_{2}$ flux (Sea-Air), and net community production (NCP). Thin dashed lines demarcate the interquartile interval (between percentiles $25 \%$ and $75 \%$ ). Only results for salinities greater than 17 are shown, since the spatiotemporal resolution from the monthly model outputs did not resolve features at lower salinities well.

model capabilities for the GoM, capturing realistically dominant seasonal patterns.

Simulated patterns in surface $p \mathrm{CO}_{2}$ across the GoM show maximum values in spring-summer and minimum in winter, with seasonally averaged values ranging from around 250 to $500 \mu \mathrm{atm}$. Seasonal variability in SST was the main driver of surface $p \mathrm{CO}_{2}$ seasonality across the GoM, except for the region around the MARS delta, where river runoff and biological uptake of DIC played a significant role during spring-summer. The $p \mathrm{CO}_{2}$-SST correlation pattern derived from the model is consistent with previous observational studies, which suggested an increased correlation between $p \mathrm{CO}_{2}$ and SST away from the Mississippi-Atchafalaya mixing zone, in open GoM waters (e.g., Lohrenz et al., 2018). Simulated patterns in surface $\Omega_{\mathrm{Ar}}$ showed maximum values in late summer and minimum in late winter, with most values ranging from 3 to 4.4 units. The meridional and crossshore gradients for model surface $\Omega_{\mathrm{Ar}}$ are consistent with patterns observed by Gledhill et al. (2008). Our model results also agree with observations by Guo et al. (2012), Wang et al. (2013), and Wanninkhof et al. (2015), which showed the most buffered surface waters off the MARS delta during summer. We found a strong positive correlation between the TA:DIC ratio and $\Omega_{\mathrm{Ar}}$, which reflects the $\Omega_{\mathrm{Ar}}$ depen- 

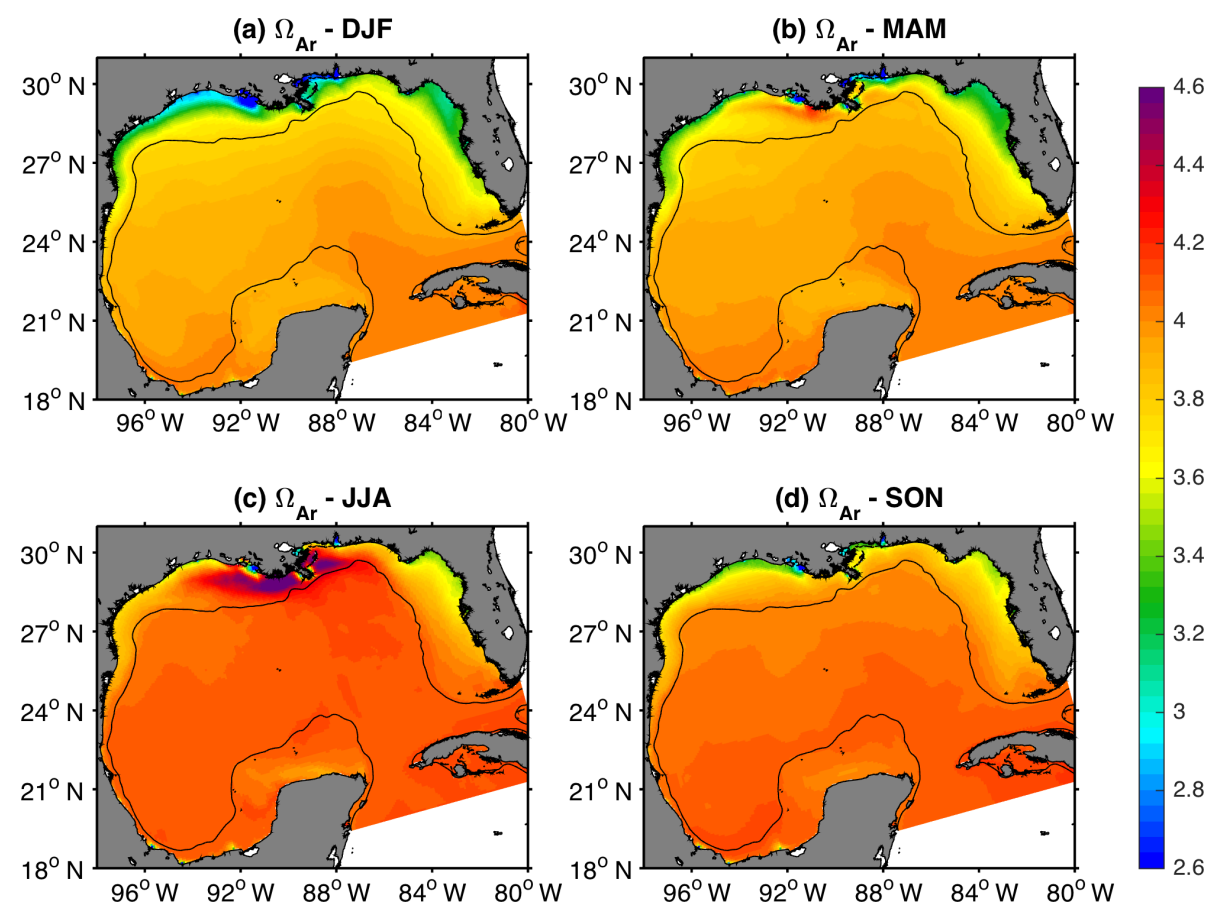

Figure 8. Mean model surface aragonite state in winter (DJF), spring (MAM), summer (JJA), and fall (SON) during 2005-2014. The black contour depicts the $200 \mathrm{~m}$ isobath.

Table 2. Comparison between annual sea-air $\mathrm{CO}_{2}$ fluxes $\left(\mathrm{molm}^{-2} \mathrm{yr}^{-1}\right)$ derived from our model results and previous studies in the Gulf of Mexico. Standard deviation is shown in parentheses. Negative flux implies ocean $\mathrm{CO}_{2}$ uptake, and positive flux $\mathrm{CO}_{2}$ outgassing (shown in bold). Shelf regions are depicted in Fig. 1.

\begin{tabular}{lrrrrrrrr}
\hline & Study type & GoM basin & Open GoM & All shelves & Northern GoM shelf & West Florida shelf & Western GoM shelf & Yucatan shelf \\
\hline Present Study & 1,3 & $-0.35(1.01)$ & $-0.33(0.87)$ & $-0.39(1.25)$ & $-0.93(1.65)$ & $-0.30(1.09)$ & $-0.22(1.24)$ & $0.0(0.75)$ \\
\hline Robbins et al. (2014) & 1,4 & $-0.19(0.08)$ & $-0.48(0.08)$ & & $-0.44(0.36)$ & $+\mathbf{0 . 3 6}(\mathbf{0 . 1 1})$ & $+\mathbf{0 . 1 8}(\mathbf{0 . 0 1})$ & $-0.09(0.05)$ \\
Robbins et al. (2018) & 1,4 & & & & $-0.95(3.7)$ & $+\mathbf{0 . 3 2}(\mathbf{1 . 5})$ & \\
Huang et al. (2015) & 1,4 & & & & $-1.1(0.3)$ & & & \\
Lohrenz et al. (2018) & 1,4 & & & & & & \\
Xue et al. (2016) & 1,3 & $-0.72(0.54)$ & $-1.04(0.46)$ & & & & \\
\hline Takahashi et al. (2009) & $2,4,5$ & $+\mathbf{0 . 2 1}$ & & & & & \\
Rödenbeck et al. (2013) & $2,4,5$ & -0.13 & & & & & \\
Landshützer et al. (2016) & $2,4,5$ & $\mathbf{+ 0 . 2 0}$ & & $-0.33(0.18)$ & & & \\
Laruelle et al. (2014) & $2,4,6$ & & & $-0.79(0.1)$ & & & \\
Bourgeois et al. (2016) & $2,3,6$ & & & & & & & \\
\hline
\end{tabular}

1: Regional study; 2: global study; 3: model-based; 4: observational-based; 5: gridded dataset; 6: Margins and Catchments Segmentation (MARCATS) dataset.

dency on changes in $\left[\mathrm{CO}_{3}^{2-}\right]$. This is consistent with Wang et al. (2013), who reported spatial covariation of these two variables over the GoM and the eastern coast of the USA. We also found a strong positive correlation between SST and $\Omega_{\mathrm{Ar}}$, which can be linked to the impact of temperature on aragonite solubility (aragonite solubility decreases with temperature) and sea-air $\mathrm{CO}_{2}$ fluxes (warm conditions favor surface DIC decrease due to $\mathrm{CO}_{2}$ outgassing, which increases the TA : DIC ratio). Comparison between monthly climatologies for surface $\Omega_{\mathrm{Ar}}$ and $\Omega_{\mathrm{Ar}}$ at25 reveals that $\Omega_{\mathrm{Ar}}$ seasonality induced by changes in the TA : DIC ratio tends to be reinforced by temperature-induced changes.
Surface $\Omega_{\text {Ar }}$ patterns can be useful to identify regions more vulnerable to ecosystem disturbances induced by surface ocean acidification. Our model indicates minimum surface $\Omega_{\text {Ar }}$ ranging from 2.5 to 3.4 on the northern GoM and west Florida inner shelves during winter, and greater than 3.4 on the western GoM and Yucatan shelves. This suggests higher ecosystem resilience to surface ocean acidification in the latter regions. Surface $\Omega_{\text {Ar }}$ patterns do not necessarily reflect vulnerability of coastal benthic organisms to ocean acidification, since $\Omega_{\mathrm{Ar}}$ values for surface and bottom layers can largely differ in regions where the water column is strongly stratified. This is the case for the Louisiana inner shelf during summer, which displayed maximum surface $\Omega_{\mathrm{Ar}}$ 


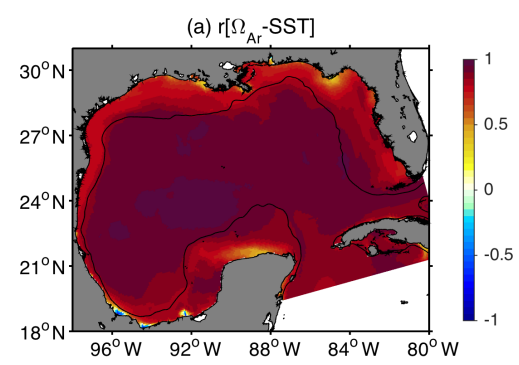

(b) $r\left[\Omega_{A r}-T A: D I C\right]$
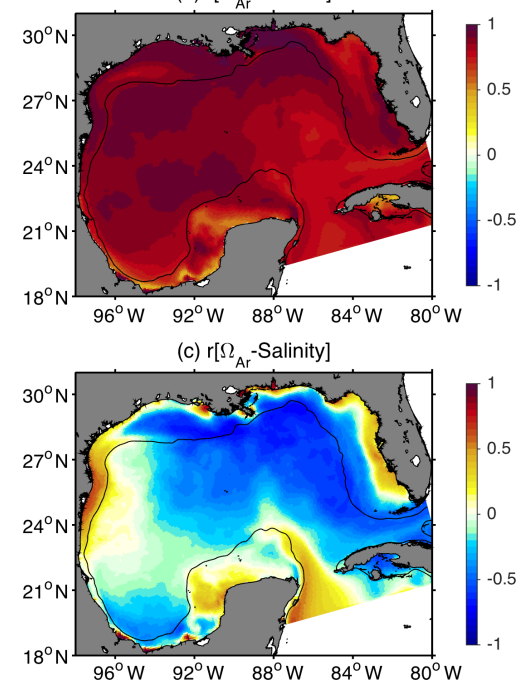

Figure 9. Correlation between surface aragonite saturation state and surface (a) temperature, (b) TA : DIC ratio, and (c) salinity. The black contour depicts the $200 \mathrm{~m}$ isobath.

values ( $>4.2$ ) linked to high biological uptake, but low bottom $\Omega_{\text {Ar }}$ values ( $<2.6$; not shown) due to bottom acidification induced by organic carbon remineralization and weak bottom ventilation (see Cai et al., 2011 and Laurent et al., 2017 for further discussion). However, our model outputs did not reveal such signatures of bottom acidification on the west Florida, western GoM, and Yucatan shelves, as these regions display relatively weak vertical stratification and lower eutrophication levels compared to the northern GoM shelf.

Sea-air $\mathrm{CO}_{2}$ flux derived from the model output shows that the $\mathrm{GoM}$ is a $\mathrm{CO}_{2}$ sink during winter-spring, and a $\mathrm{CO}_{2}$ source during summer-fall. However, significant differences in the annual flux magnitude were observed among regions, which could be associated with distinct ocean biogeochemical regimes. The northern GoM shelf, a river-dominated ocean margin strongly influenced by seasonal patterns in MARS runoff (McKee et al., 2004; Cai et al., 2013), is the coastal region with the lowest surface $p \mathrm{CO}_{2}$ and the largest $\mathrm{CO}_{2}$ uptake from the model. This pattern is due to the substantial cooling experienced by the northern GoM shelf during winter (linked to its northernmost location), and the enhanced biological uptake promoted by river runoff near the MARS delta during spring-summer. Our results support the
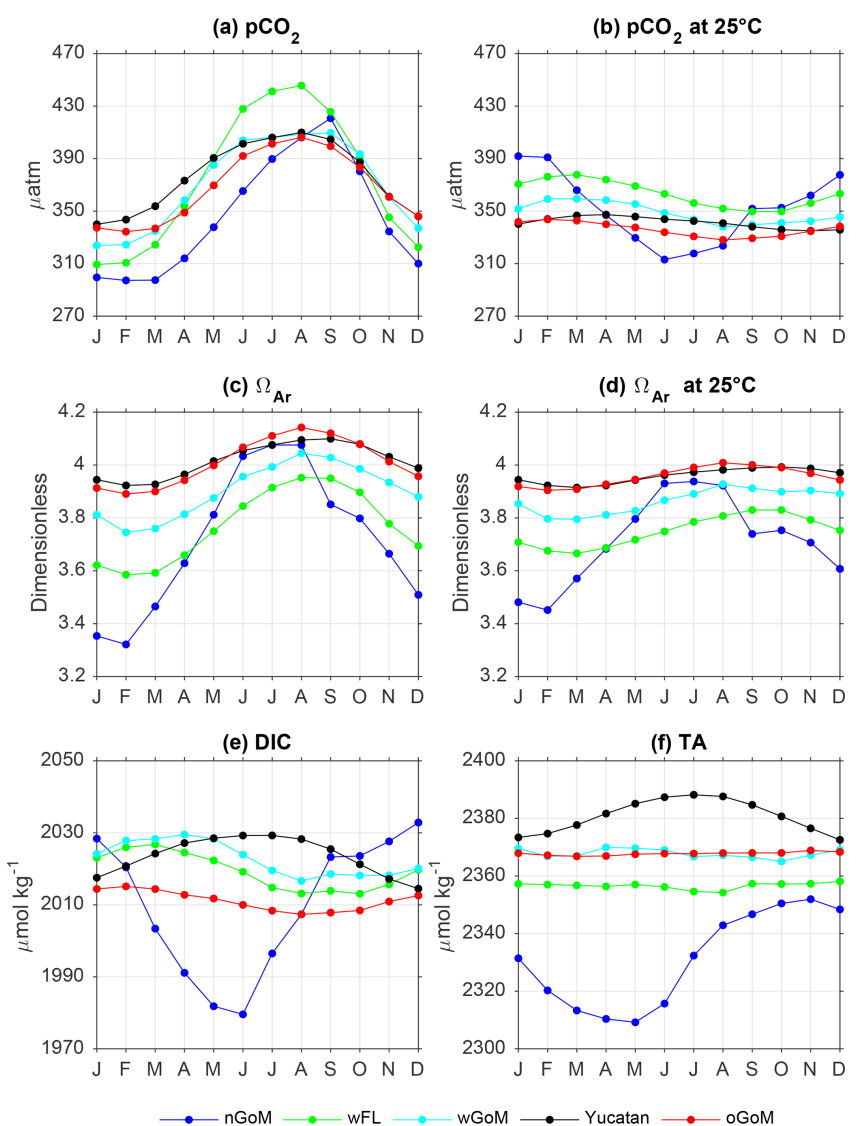

Figure 10. Figure 10. Monthly climatology for model (a) $p \mathrm{CO}_{2}$, (b) $p \mathrm{CO}_{2}$ at $25^{\circ} \mathrm{C}$, (c) aragonite saturation state $\left(\Omega_{\mathrm{Ar}}\right)$, (d) $\Omega_{\mathrm{Ar}}$ at $25^{\circ} \mathrm{C}$, (e) dissolved inorganic carbon (DIC), and (f) total alkalinity (TA) in northern GoM shelf (nGoM; blue), west Florida shelf (wFL; green), western GoM shelf (wGoM; cyan), Yucatan shelf (black), and open GoM (oGoM, red). Patterns were derived for 2005-2014.

framework proposed by Huang et al. (2015) for the Mississippi River plume during spring-summer, which indicates (i) high $p \mathrm{CO}_{2}$ levels and $\mathrm{CO}_{2}$ outgassing at low salinities $(<20)$, linked to the low productivity, high turbidity, and $\mathrm{CO}_{2}$ oversaturated waters delivered by the Mississippi River; (ii) minimum $p \mathrm{CO}_{2}$ values and maximum atmospheric $\mathrm{CO}_{2}$ uptake at middle salinities (20-33), as high phytoplankton production, induced by the water's lower turbidity and decreased nutrient runoff, produces a drop in surface DIC, and (iii) increased $p \mathrm{CO}_{2}$ levels and sea-air $\mathrm{CO}_{2}$ flux at high salinities (>33), as phytoplankton production declines offshore in the oligotrophic open GoM waters. In the west Florida and western GoM shelves, two coastal margins that are not strongly influenced by river runoff, temperature plays a dominant role as driver of $p \mathrm{CO}_{2}$ and sea-air $\mathrm{CO}_{2}$ flux seasonality. As a result, the annually integrated sea-air $\mathrm{CO}_{2}$ flux $\left(\right.$ per $\mathrm{m}^{2}$ ) in these two shelves represents only $31 \%$ and $23 \%$ of the simulated carbon uptake in the northern GoM, respectively. In the Yucatan Peninsula, temperature is like- 


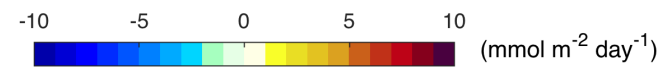

(a) $\mathrm{CO}_{2}$ flux - DJF

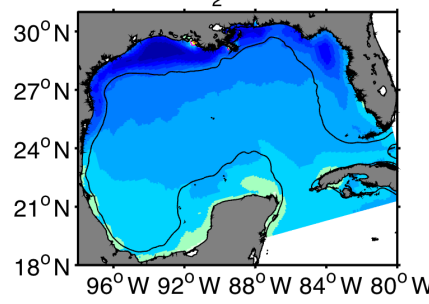

(c) $\mathrm{CO}_{2}$ flux - JJA

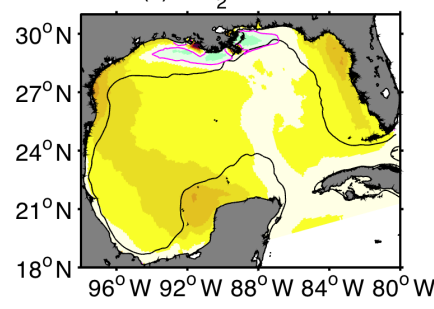

(e) $\mathrm{CO}_{2}$ flux - annual mean
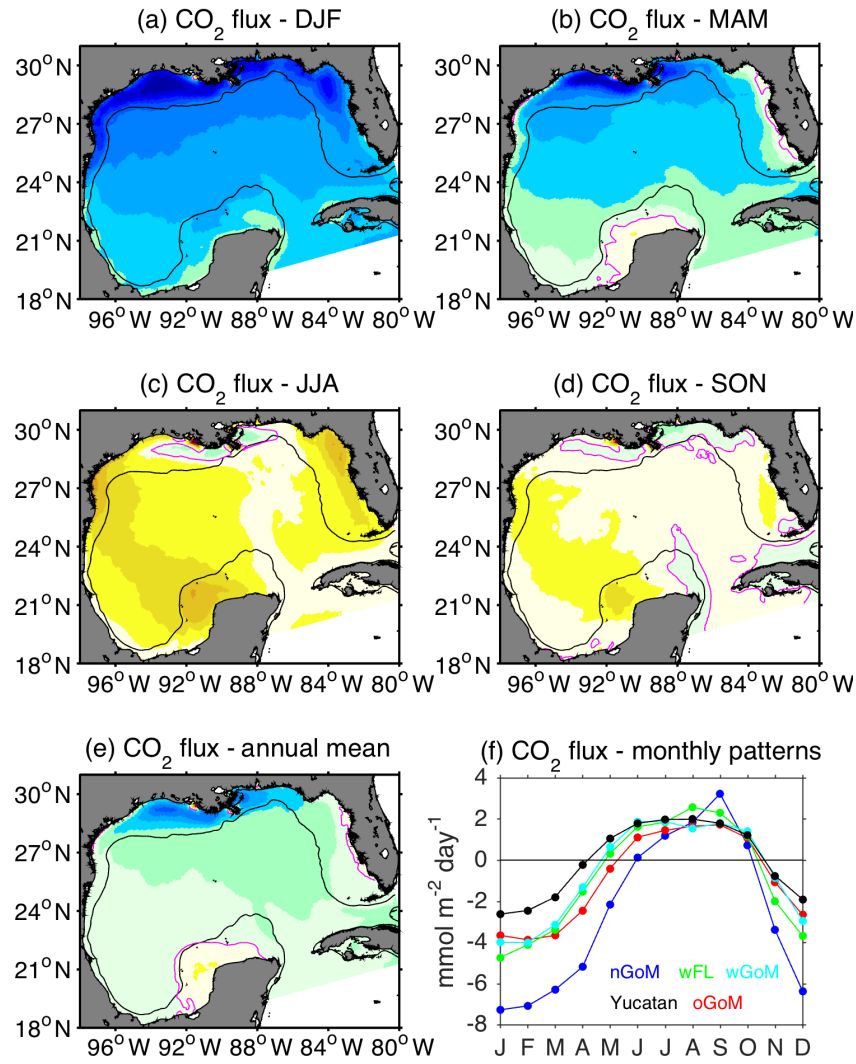

(d) $\mathrm{CO}_{2}$ flux - SON

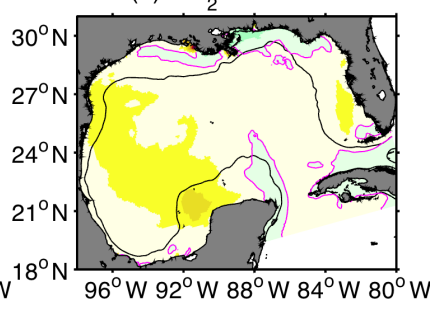

(f) $\mathrm{CO}_{2}$ flux - monthly patterns

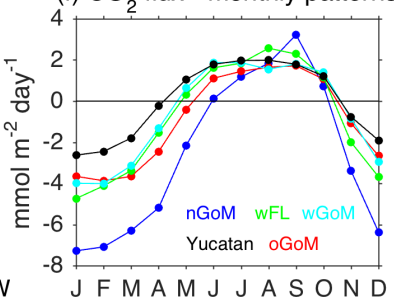

Figure 11. Model sea-air $\mathrm{CO}_{2}$ flux $\left(\mathrm{mmol} \mathrm{m}^{-2} \mathrm{~d}^{-1}\right)$ patterns during 2005-2014. (a-d) Spatial mean patterns for (a) winter (DJF), (b) spring (MAM), (c) summer (JJA), and (d) fall (SON). (e) Spatial annual mean. (f) Monthly climatology for the northern GoM shelf (nGoM; blue), west Florida shelf (wFL; green), western GoM shelf (wGoM; cyan), Yucatan shelf (black), and open GoM (oGoM, red). Negative (positive) flux implies ocean uptake (degassing). The magenta contours in panels (a-e) depict $0 \mathrm{mmolm}^{-2} \mathrm{~d}^{-1}$, and black contours the $200 \mathrm{~m}$ isobath.

wise the main driver of model surface $p \mathrm{CO}_{2}$ and $\mathrm{CO}_{2}$ flux seasonality. The zero flux in this region results from a less pronounced winter cooling, which determines a relatively weak carbon uptake during winter-spring. However, winddriven upwelling also plays a role by increasing model surface $p \mathrm{CO}_{2}$ during spring, especially nearshore. Although previous studies have documented the impact of coastal upwelling on SST and surface chlorophyll in the Yucatan shelf (e.g., Zavala-Hidalgo et al., 2006), no study has addressed the associated impact on carbon chemistry, as insufficient inorganic carbon observations exist for this region. Further observational studies are required therefore to corroborate this dynamic. Finally, the simulated annual carbon uptake was weak for most of the GoM basin. Therefore, it is likely that relatively small disturbances in the $p \mathrm{CO}_{2}$ drivers could turn the carbon sink regions into carbon sources. A potential

mechanism for this change is ocean warming, since future ocean projections in the GoM suggest a significant SST increase $\left(>2{ }^{\circ} \mathrm{C}\right)$ due to anthropogenic climate change through the end of the twenty-first century (Liu et al., 2012, 2015; Alexander et al., 2020; Shin and Alexander, 2020). This is topic deserves examination in future modeling efforts.

\section{2 $\mathrm{CO}_{2}$ flux comparison}

Table 2 shows mean $\mathrm{CO}_{2}$ fluxes derived from our model, previous regional studies for the GoM, and global datasets. The regional-scale studies are Robbins et al. (2014; 2018), Huang et al. (2015), Xue et al. (2016), and Lohrenz et al. (2018). The global-scale studies include Takahashi et al. (2009), Rödenbeck et al. (2013), Landshützer et al. (2016), Laruelle et al. (2014), and Bourgeois et al. (2016). Annual $\mathrm{CO}_{2}$ fluxes for the GoM basin displayed a significant dispersion, ranging from -0.72 to $+0.20 \mathrm{~mol} \mathrm{~m}^{-2} \mathrm{yr}^{-1}$. However, the three regional studies providing basin-wide estimates (including ours) agree that the GoM is a carbon sink. We obtained an average value of $-0.35 \mathrm{~mol} \mathrm{~m}^{-2} \mathrm{yr}^{-1}$, which is comparable with Robbins et al. (2014) and Xue et al. (2016) estimates. In contrast, two of three basin fluxes derived from global gridded datasets, Takahashi et al. (2009) and Landshützer et al. (2016), suggest that the GoM is a weak $\mathrm{CO}_{2}$ source. This discrepancy between regional and global studies most likely reflects inaccuracy in global datasets, due to the low density of $p \mathrm{CO}_{2}$ observations in the GoM basin and coarse grid resolutions $\left(5^{\circ}\right.$ latitude $\times 4^{\circ}$ longitude in Takahashi et al. 2009 and $1^{\circ}$ latitude $\times 1^{\circ}$ longitude in Landshützer et al. 2016).

We obtained fluxes that are in reasonable agreement with observation-based fluxes for most of the sub-regions depicted in Fig. 1. In the open GoM region, our mean flux $\left(-0.33 \mathrm{~mol} \mathrm{~m}^{-2} \mathrm{yr}^{-1}\right)$ is about $70 \%$ of the flux derived by Robbins et al. (2014). For all four GoM shelf regions combined (west Florida, northern GoM, western GoM, and Yucatan), our estimated flux $\left(-0.39 \mathrm{molm}^{-2} \mathrm{yr}^{-1}\right)$ is $20 \%$ above the value reported by Laruelle et al. (2014). In the northern GoM, our simulated flux $\left(-0.93 \mathrm{~mol} \mathrm{~m}^{-2} \mathrm{yr}^{-1}\right)$ is remarkably similar to the reported fluxes of Huang et al. (2015) and Lohrenz et al. (2018; -0.95 and $-1.1 \mathrm{~mol} \mathrm{~m}^{-2} \mathrm{yr}^{-1}$, respectively). In the Yucatan Peninsula, our zero flux condition is close to the weak uptake condition derived by Robbins et al. (2014; $-0.09 \mathrm{~mol} \mathrm{~m}^{-2} \mathrm{yr}^{-1}$ ). The major disagreement between our estimates and previous studies is on the west Florida and western GoM shelves. We determined that these two regions are carbon sinks $\left(-0.30\right.$ and $-0.22 \mathrm{~mol} \mathrm{~m}^{-2} \mathrm{yr}^{-1}$, respectively), whereas observational studies by Robbins et al. (2014, 2018), as well as the modeling study by Xue et al. (2016), estimated a mean carbon outgassing condition. Some overestimation in our modeled $\mathrm{CO}_{2}$ uptake is possible, as the model surface $p \mathrm{CO}_{2}$ in the open GoM tended to be underestimated during late winter and spring. However, the observational uncertainty 
in Robins et al. $(2014,2018)$ also needs to be considered. The dataset of underway $p \mathrm{CO}_{2}$ measurements, used to generate the observed bulk $\mathrm{CO}_{2}$ fluxes, has very limited spatial coverage over the western GoM. Also, this dataset has a reduced number of winter observations in west Florida and other GoM regions (only $8 \%$ of the GoM data were collected in December-February, less than $2 \%$ during January). A correct estimation of the winter flux is important, as this season largely determines the sign of the annual flux. Indeed, excluding winter, our simulated spring-to-fall flux for west Florida is positive $\left(+0.12 \mathrm{~mol} \mathrm{~m}^{-2} \mathrm{yr}^{-1}\right)$.

The simulated fluxes largely differ from the fluxes reported by Xue et al. (2016), which was the only previous regional modeling study describing basin wide patterns in the GoM. They obtained a three times stronger uptake in the open GoM, and much weaker uptake in the shelf regions (e.g., their simulated annual flux for the northern GoM shelf was one-third of our estimation). We believe these differences in $\mathrm{CO}_{2}$ fluxes can be explained mainly by $p \mathrm{CO}_{2}$ biases in the model used in Xue et al. (2016). Indeed, their model underestimated surface $p \mathrm{CO}_{2}$ in the open $\mathrm{GoM}$, and thus obtained a marked $p \mathrm{CO}_{2}$ minimum over the Loop Current region (see their Fig. 13a), a pattern not supported by SOOP observations (Fig. S6). In addition, their model largely overestimated surface $p \mathrm{CO}_{2}$ on the northern GoM and west Florida inner shelves, especially during summer-fall, not reproducing well the marked $p \mathrm{CO}_{2}$ drop that is observed close to the MARS delta.

\section{Summary and conclusions}

We configured a coupled ocean biogeochemical model to examine inorganic carbon chemistry patterns in the GoM. The model was validated against observations from a coastal buoy, research cruises, and ships of opportunity, showing smaller seasonal and regional bias for surface $p \mathrm{CO}_{2}$ than previous modeling efforts in the region. We described seasonal patterns in surface $p \mathrm{CO}_{2}$ and $\Omega_{\mathrm{Ar}}$. Both variables show maximum values during late summer and minimum during winter and early spring. The seasonal cycle for $p \mathrm{CO}_{2}$ is strongly controlled by temperature, while $\Omega_{\mathrm{Ar}}$ follows changes in the TA:DIC ratio and temperature. Model results also indicated that river runoff- and wind-driven circulation significantly influence coastal DIC and TA patterns in coastal regions, impacting $\Omega_{\mathrm{Ar}}, p \mathrm{CO}_{2}$, and sea-air $\mathrm{CO}_{2}$ flux seasonality. Simulated fluxes show $\mathrm{CO}_{2}$ uptake prevailing during winter-spring, and $\mathrm{CO}_{2}$ outgassing during summer-fall. The integrated annual flux for the GoM basin is $-0.35 \mathrm{~mol} \mathrm{~m}^{-2} \mathrm{yr}^{-1}\left(-4.2 \mathrm{~g} \mathrm{Cm}^{-2} \mathrm{yr}^{-1}\right)$. The largest model $\mathrm{CO}_{2}$ uptake is in the northern GoM shelf, linked to the most intense winter cooling, and significant biological uptake during spring-summer. The weakest $\mathrm{CO}_{2}$ uptake is in the Yucatan Peninsula, mainly a consequence of the relatively warm conditions experienced by this region during winter-spring, and to a less degree wind-driven upwelling of DIC-rich waters. Sub-regional estimates are in general consistent or close to previous observational studies, with the exception of the west Florida and western GoM shelves. We suggest that part of these discrepancies could be related to the still reduced spatiotemporal coverage in the underway $p \mathrm{CO}_{2}$ measurement dataset over those two regions, especially during wintertime.

Data availability. The ocean biogeochemical model outputs used in this study are available in the Network Common Data Form (NetCDF) format on the NOAA-AOML server.

Supplement. The supplement related to this article is available online at: https://doi.org/10.5194/bg-17-1685-2020-supplement.

Author contributions. SKL, RW, LB, and FAG designed the study. FAG configured the model and performed the model simulations. RW and LB provided the validation dataset. FAG wrote the paper with contributions from all the authors.

Competing interests. The authors declare that they have no conflict of interest.

Acknowledgements. We thank the two anonymous reviewers and Ruben van Hooidonk (CIMAS/AOML) for their valuable comments and suggestions. This article was supported by the Northern Gulf Institute, NOAA's Ocean Acidification Program (OAP), and NOAA's Atlantic Oceanographic and Meteorological Laboratory (AOML) NOAA's OAP and NOAA's Climate Program Office provided funding and support for surface $p \mathrm{CO}_{2}$ data collection. This research was carried out, in part, under the auspices of the Cooperative Institute for Marine and Atmospheric Studies (CIMAS), a Cooperative Institute of the University of Miami and the NOAA.

Financial support. This research has been supported by the Northern Gulf Institute (grant no. 191001-363513-3C) and the Cooperative Institute for Marine and Atmospheric Studies (grant no. NA10OAR4320143).

Review statement. This paper was edited by Stefano Ciavatta and reviewed by two anonymous referees.

\section{References}

Alexander, M. A., Shin, S. I., Scott, J. D., Curchitser, E., and Stock, C.: The Response of the Northwest Atlantic Ocean to Climate Change, J. Clim., 33, 405-428, 2020. 
Anglès, S., Jordi, A., Henrichs, D. W., and Campbell, L.: Influence of coastal upwelling and river discharge on the phytoplankton community composition in the northwestern Gulf of Mexico, Prog. Oceanogr., 173, 26-36, https://doi.org/10.1016/j.pocean.2019.02.001, 2019.

Aulenbach, B. T., Buxton, H. T., Battaglin, W. T., and Coupe, R. H.: Streamflow and nutrient fluxes of the Mississippi-Atchafalaya River Basin and subbasins for the period of record through 2005, US Geological Survey Open-File Report, 2007-1080, 2007.

Bourgeois, T., Orr, J. C., Resplandy, L., Terhaar, J., Ethé, C., Gehlen, M., and Bopp, L.: Coastal-ocean uptake of anthropogenic carbon, Biogeosciences, 13, 4167-4185, https://doi.org/10.5194/bg-13-4167-2016, 2016.

Cai, W. J.: Riverine inorganic carbon flux and rate of biological uptake in the Mississippi River plume, Geophys. Res. Lett., 30, 1032, https://doi.org/10.1029/2002GL016312, 2003.

Cai, W.-J., Hu, X., Huang, W.-J., Murrell, M. C., Lehrter, J. C., Lohrenz, S. E., Chou, W.-C., Zhai, W., Hollibaugh, J. T., Wang, Y., Zhao, P., Guo, X., Gundersen, K., Dai, M., and Gong, G.-C.: Acidification of subsurface coastal waters enhanced by eutrophication, Nat. Geosci., 4, 766-770, 2011.

Cai, W.-J., Chen, C. T. A., and Borges, A.: Carbon dioxide dynamics and fluxes in coastal waters influenced by river plumes, in: Biogeochemical Dynamics at Major River-Coastal Interfaces, edited by: Bianchi, T. S., Allison M. A., and Cai, W.-J., Cambridge University Press, Cambridge, 155-173, https://doi.org/10.1017/CBO9781139136853.010, 2013.

Chavez, F., Takahashi, P. T., Cai, W. J., Friederich, G. E., Hales, B., Wanninkhof, R., and Feely, R. A.: Coastal oceans, chap. 15, in: First State of the Carbon Cycle Report (SOCCR): The North American Carbon Budget and Implications for the Global Carbon Cycle. A Report by the U.S. Climate Change Science Program and the Subcommittee on Global Change Research, edited by: King, A., Dilling, W. L., Zimmerman, G. P., Fairman, D. M., Houghton, R. A., Marland, G., Rose, A. Z., and Wilbanks, T., National Oceanic and Atmospheric Administration, National Climatic Data Center, Asheville, 157-166, 2007.

Dagg, M. J. and Breed, G. A.: Biological effects of Mississippi River nitrogen on the northern Gulf of Mexico - a review and synthesis, J. Mar. Syst., 43, 133-152, 2003.

Dee, D. P., Uppala, S. M., Simmons, A. J., Berrisford, P., Poli, P., Kobayashi, S., Andrae, U., Balmaseda, M. A., Balsamo, G., Bauer, P., and Bechtold, P.: The ERA-Interim reanalysis: Configuration and performance of the data assimilation system, Q. J. Roy. Meteorol. Soc., 137, 553-597, 2011.

Dickson, A. G.: Standard potential of the reaction: $\mathrm{AgCl}(\mathrm{s})+12 \mathrm{H}_{2}(\mathrm{~g})=\mathrm{Ag}(\mathrm{s})+\mathrm{HCl}(\mathrm{aq})$, and the standard acidity constant of the ion $\mathrm{HSO}_{4}^{-}$in synthetic sea water from 273.15 to $318.15 \mathrm{~K}$, J. Chem. Thermodynam., 22, 113-127, 1990a.

Dickson, A. G.: Thermodynamics of the dissociation of boric acid in synthetic seawater from 273.15 to 318.15 K, Deep-Sea Res. Pt. A, 37, 755-766, 1990b.

Dickson, A. G. and F. Millero, J.: A comparison of the equilibrium constants for the dissociation of carbonic acid in seawater media, Deep-Sea Res. Pt. A, 34, 1733-1743, 1987.

Doney, S. C., Ruckelshaus, M., Duffy, J. E., Barry, J. P., Chan, F., English, C. A., Galindo, H. M., Grebmeier, J. M., Hollowed, A. B., Knowlton, N., Polovina, J., Rabalais, N. N., Sydeman, W. J., and Talley, L. D.: Climate change impacts on marine ecosystems, Annu. Rev. Mar. Sci., 4, 11-37, 2012.

Dunne, J. P., John, J. G., Shevliakova, E., Stouffer, R. J., Krasting, J. P., Malyshev, S. L., Milly, P . C. D., Sentman, L. T., Adcroft, A. J., Cooke, W., and Dunne, K. A.: GFDL's ESM2 global coupled climate-carbon earth system models, Part II: carbon system formulation and baseline simulation characteristics, J. Clim., 26, 2247-2267, 2013.

Fennel, K. and Wilkin, J.: Quantifying biological carbon export for the northwest North Atlantic continental shelves, Geophys. Res. Lett., 36, L18605, https://doi.org/10.1029/2009g1039818, 2009.

Fennel, K., Wilkin, J., Previdi, M., and Najjar, R.: Denitrification effects on air-sea $\mathrm{CO}_{2}$ flux in the coastal ocean: Simulations for the northwest North Atlantic, Geophys. Res. Lett., 35, L24608, https://doi.org/10.1029/2008gl036147, 2008.

Fennel, K., Alin, S., Barbero, L., Evans, W., Bourgeois, T., Cooley, S., Dunne, J., Feely, R. A., Hernandez-Ayon, J. M., Hu, X., Lohrenz, S., Muller-Karger, F., Najjar, R., Robbins, L., Shadwick, E., Siedlecki, S., Steiner, N., Sutton, A., Turk, D., Vlahos, P., and Wang, Z. A.: Carbon cycling in the North American coastal ocean: a synthesis, Biogeosciences, 16, 1281-1304, https://doi.org/10.5194/bg-16-1281-2019, 2019.

Gledhill, D. K., Wanninkhof, R., Millero, F. J., and Eakin, M.: Ocean acidification of the greater Caribbean region 1996-2006, J. Geophys. Res.-Ocean., 113, C10031, https://doi.org/10.1029/2007JC004629, 2008.

Gomez, F. A., Lee, S.-K., Liu, Y., Hernandez Jr., F. J., MullerKarger, F. E., and Lamkin, J. T.: Seasonal patterns in phytoplankton biomass across the northern and deep Gulf of Mexico: a numerical model study, Biogeosciences, 15, 3561-3576, https://doi.org/10.5194/bg-15-3561-2018, 2018.

Green, R. E., Breed, G. A., Dagg, M. J., and Lohrenz, S. E.: Modeling the response of primary production and sedimentation to variable nitrate loading in the Mississippi River plume, Cont. Shelf Res., 28, 1451-1465, 2008.

Gruber, N., Clement, D., Carter, B. R., Feely, R. A., Van Heuven, S., Hoppema, M., Ishii, M., Key, R. M., Kozyr, A., Lauvset, S. K., and Monaco, C. L.: The oceanic sink for anthropogenic $\mathrm{CO}_{2}$ from 1994 to 2007, Science, 363, 1193-1199, 2019.

Guo, X., Cai, W. J., Huang, W. J., Wang, Y., Chen, F., Murrell, M. C., Lohrenz, S. E., Jiang, L. Q., Dai, M., Hartmann, J., and Lin, Q.: Carbon dynamics and community production in the Mississippi River plume, Limnol. Oceanogr., 57, 1-17, 2012.

He, B., Kanae, S., Oki, T., Hirabayashi, Y., Yamashiki, Y., and Takara, K.: Assessment of global nitrogen pollution in rivers using an integrated biogeochemical modeling framework, Water Res., 45, 2573-2586, 2011.

Hu, X., Nuttall, M. F., Wang, H., Yao, H., Staryk, C. J., McCutcheon, M. R., Eckert, R. J., Embesi, J. A., Johnston, M. A., Hickerson, E. L., Schmahl, G. P., Manzello, D. Enochs, I. C., DiMarco, S., and Barbero, L.: Seasonal variability of carbonate chemistry and decadal changes in waters of a marine sanctuary in the Gulf of Mexico, Mar. Chem., 205, 16-28, 2018.

Huang, W.-J., Cai, W.-J., Powell, R. T., Lohrenz, S. E., Wang, Y., Jiang, L.-Q., and Hopkinson, C. S.: The stoichiometry of inorganic carbon and nutrient removal in the Mississippi River plume and adjacent continental shelf, Biogeosciences, 9, 2781-2792, https://doi.org/10.5194/bg-9-2781-2012, 2012. 
Huang, W. J., Cai, W. J., Wang, Y., Lohrenz, S. E., and Murrell, M. C.: The carbon dioxide system on the Mississippi River dominated continental shelf in the northern Gulf of Mexico: 1. Distribution and air-sea $\mathrm{CO}_{2}$ flux, J. Geophys. Res.-Ocean., 120, 1429-1445, 2015.

Landschützer, P., Gruber, N., and Bakker, D. C. E.: Decadal variations and trends of the global ocean carbon sink, Global Biogeochem. Cy., 30, 1396-1417, https://doi.org/10.1002/2015GB005359, 2016.

Laruelle, G. G., Lauerwald, R., Pfeil, B., and Regnier, P.: Regionalized global budget of the $\mathrm{CO}_{2}$ exchange at the air-water interface in continental shelf seas, Global Biogeochem. Cy., 28, 1199-1214, 2014.

Laurent, A., Fennel, K., Cai, W.-J., Huang, W.-J., Barbero, L., and Wanninkhof, R.: Eutrophication-induced acidification of coastal waters in the northern Gulf of Mexico: Insights into origin and processes from a coupled physical-biogeochemical model, Geophys. Res. Lett., 44, 946-956, 2017.

Lehrter, J. C., Ko, D. S., Murrell, M. C., Hagy, J. D., Schaeffer, B. A., Greene, R. M., Gould, R. W., and Penta, B.: Nutrient distributions, transports, and budgets on the inner margin of a river-dominated continental shelf, J. Geophys. Res.-Ocean., 118, 4822-4838, 2013.

Liu, Y., Lee, S. -K., Muhling, B. A., Lamkin J. T., and Enfield, D. B.: Significant reduction of the Loop Current in the 21st century and its impact on the Gulf of Mexico, J. Geophys. Res., 117, C05039, https://doi.org/10.1029/2011JC007555, 2012.

Liu, Y., Lee, S. K., Enfield, D. B., Muhling, B. A., Lamkin, J. T., Muller-Karger, F. E., and Roffer, M. A.: Potential impact of climate change on the Intra-Americas Sea: Part-1, A dynamic downscaling of the CMIP5 model projections, J. Mar. Syst., 148, 56-69, 2015.

Lohrenz, S. E., Cai, W. J., Chen, F., Chen, X., and Tuel, M.: Seasonal variability in air-sea fluxes of $\mathrm{CO}_{2}$ in a riverinfluenced coastal margin, J. Geophys. Res.-Oceans., 115, C10034, https://doi.org/10.1029/2009JC005608, 2010.

Lohrenz, S. E., Cai, W.-J., Chakraborty, S., Huang, W.-J., Guo, X., He, R., Xue, Z., Fennel, K., Howden, S., and Tian, H.: Satellite estimation of coastal $p \mathrm{CO}_{2}$ and air-sea flux of carbon dioxide in the northern Gulf of Mexico, Remote Sens. Environ., 207, 71-83, 2018.

Martínez-López and B. and Zavala-Hidalgo, J.: Seasonal and interannual variability of cross-shelf transports of chlorophyll in the Gulf of Mexico, J. Mar. Syst., 77, 1-20, 2009.

McKee, B. A., Aller, R. C., Allison, M. A., Bianchi, T. S., and Kineke, G. C.: Transport and transformation of dissolved and particulate materials on continental margins influenced by major rivers: benthic boundary layer and seabed processes, Cont. Shelf Res., 24, 899-926, 2004.

Mehrbach, C., Culberson, C. H., Hawley, J. E., and Pytkowicz, R. M.: Measurement of the apparent dissociation constants of carbonic acid in seawater at atmospheric pressure, Limnol. Oceanogr., 18, 897-907, 1973.

Millero, F. J.: Thermodynamics of the carbon dioxide system in the oceans, Geochim. Cosmochim. Ac., 59, 661-677, 1995.

Mostofa, K. M. G., Liu, C.-Q., Zhai, W., Minella, M., Vione, D., Gao, K., Minakata, D., Arakaki, T., Yoshioka, T., Hayakawa, K., Konohira, E., Tanoue, E., Akhand, A., Chanda, A., Wang, B., and Sakugawa, H.: Reviews and Syntheses: Ocean acidification and its potential impacts on marine ecosystems, Biogeosciences, 13, 1767-1786, https://doi.org/10.5194/bg-13-1767-2016, 2016.

Mucci, A.: The solubility of calcite and aragonite in seawater at various salinities, temperatures, and one atmosphere total pressure, Am. J. Sci., 283, 780-799, https://doi.org/10.2475/ajs.283.7.780, 1983.

Muller-Karger, F. E., Smith, J. P., Werner, S., Chen, R., Roffer, M., Liu, Y., Muhling, B., Lindo-Atichati, D., Lamkin, J., CerdeiraEstrada, S., and Enfield, D. B.: Natural variability of surface oceanographic conditions in the offshore Gulf of Mexico, Prog. Oceanogr., 134, 54-76, 2015.

Muñoz-Salinas, E. and Castillo, M.: Streamflow and sediment load assessment from 1950 to 2006 in the Usumacinta and Grijalva Rivers (Southern Mexico) and the influence of ENSO, Catena, 127, 270-278, 2015.

Orr, J., Fabry, V., Aumont, O., Bopp, L., Doney, S., Feely, R., Gnanadesikan, A., Gruber, N., Ishida, A., Joos, F., Key, R., Lindsay, K., Maier-Reimer, E., Matear, R., Monfray, P., Mouchet, A., Najjar, R., Plattner, G., Rodgers, K., Sabine, C., Sarmiento, J., Schlitzer, R., Slater, R., Totterdell, I., Weirig, M., Yamanaka, Y., and Yool, A.: Anthropogenic ocean acidification over the twenty first century and its impact on calcifying organisms, Nature, 437, 681-686, 2005.

Robbins, L. L., Wanninkhof, R., Barbero, L., Hu, X., Mitra, S., Yvon-Lewis, S., Cai,W.-J., Huang,W.-J., and Ryerson, T.: Airsea exchange, in: Report of the U.S. Gulf of Mexico Carbon Cycle Synthesis Workshop, March 27-28, 2013, edited by: Benway, H. M. and Coble, P. G., Ocean Carbon and Biogeochemistry Program and North American Carbon Program, U.S. Geological Survey, St. Petersburg, Florida, USA, 17-23, 2014.

Robbins, L., Daly, K., Barbero, L., Wanninkhof, R., He, R., Zong, H., Lisle, J., Cai, W.-J., and Smith, C.: Spatial and temporal variability of $p \mathrm{CO}_{2}$, carbon fluxes and saturation state on the West Florida Shelf, J. Geophys. Res.-Ocean., 123, 6174-6188, https://doi.org/10.1029/2018jc014195, 2018.

Rödenbeck, C., Keeling, R. F., Bakker, D. C. E., Metzl, N., Olsen, A., Sabine, C., and Heimann, M.: Global surface-ocean $p \mathrm{CO}_{2}$ and sea-air $\mathrm{CO}_{2}$ flux variability from an observationdriven ocean mixed-layer scheme, Ocean Sci., 9, 193-216, https://doi.org/10.5194/os-9-193-2013, 2013.

Sabine, C. L., Feely, R. A., Gruber, N., Key, R. M., Lee, K., Bullister, J. L., Wanninkhof, R., Wong, C. S., Wallace, D. W. R., Tilbrook, B., Millero, F. J., Peng, T.-H., Kozyr, A., Ono, T., and Rios, A. F.: The oceanic sink for anthropogenic $\mathrm{CO}_{2}$, Science, 305, 367-371, 2004.

Shchepetkin, A. F. and McWilliams, J. C.: The regional oceanic modeling system (ROMS): a split-explicit, free-surface, topography-following-coordinate oceanic model, Ocean Model., 9347-404, 2005.

Shin, S. and Alexander, M. A.: Dynamical downscaling of future hydrographic changes over the Northwest Atlantic Ocean, J. Clim., 3, 2871-2890, https://doi.org/10.1175/JCLI-D-19-0483.1, 2020.

Stets, E. G. and Striegl, R. G.: Carbon export by rivers draining the conterminous United States, Inland Waters, 2, 177-184, 2012.

Stets, E. G., Kelly, V. J., and Crawford, C. G.: Long-term trends in alkalinity in large rivers of the conterminous US in relation to acidification, agriculture, and hydrologic modification, Sci. Total Environ., 488, 280-289, 2014. 
Sutton, A., Sabine, C., Howden, S., Musielewicz, S., Maenner, S., Dietrich, C., Bott, R., and Osborne, J.: High-resolution ocean and atmosphere $p \mathrm{CO}_{2}$ time-series measurements from mooring CoastalMS_88W_30N, Carbon Dioxide Information Analysis Center, Oak Ridge National Laboratory, US Department of Energy, Oak Ridge, Tennessee, https://doi.org/10.3334/CDIAC/OTG.TSM_COASTALMS_88W_30N 2014.

Takahashi, T., Sutherland, S. C., Wanninkhof, R., Sweeney, C., Feely, R. A., Chipman, D. W., Hales, B., Friederich, G., Chavez, F., Sabine, C., and Watson, A.: Climatological mean and decadal change in surface ocean $p \mathrm{CO}_{2}$, and net sea-air $\mathrm{CO}_{2}$ flux over the global oceans, Deep-Sea Res. Pt. II, 56, 554-577, 2009.

Thoning, K. W., Tans, P. P., and Komhyr, W. D.: Atmospheric carbon dioxide at Mauna Loa Observatory, 2. Analysis of the NOAA/GMCC data, 1974-1985, J. Geophys. Res., 94, 8549$8565,1989$.

van Heuven, S. M. A. C., Pierrot, D., Rae, J. W. B., Lewis, E., and Wallace, D. W. R.: MATLAB program developed for $\mathrm{CO}_{2}$ system calculations, ORNL/CDIAC-105b, Carbon Dioxide Information Analysis Center, Oak Ridge National Laboratory, US Department of Energy, Oak Ridge, Tennessee, https://doi.org/10.3334/CDIAC/otg.CO2SYS_MATLAB_v1.1, 2011.
Wang, Z. A., Wanninkhof, R., Cai, W.-J., Byrne, R. H., Hu, X., Peng, T.-H., and Huang,W.-J.: The marine inorganic carbon system along the Gulf of Mexico and Atlantic coasts of the United States: Insights from a transregional coastal carbon study, Limnol. Oceanogr., 58, 325-342, 2013.

Wanninkhof, R.: Relationship between wind speed and gas ex$30 \mathrm{~N}$, change over the ocean revisited, Limnol. Oceanogr.-Method., 12, 351-362, 2014

Wanninkhof, R., Barbero, L., Byrne, R., Cai, W.-J., Huang, W.-J., Zhang, J.-Z., Baringer, M., and Langdon, C.: Ocean acidification along the Gulf Coast and East Coast of the USA, Cont. Shelf Res., 98, 54-71, 2015.

Wolf-Gladrow, D. A., Zeebe, R. E., Klaas, C., Körtzinger, A., and Dickson, A. G.: Total alkalinity: The explicit conservative expression and its application to biogeochemical processes, Mar. Chem., 106, 287-300, 2007.

Xue, Z., He, R., Fennel, K., Cai, W.-J., Lohrenz, S., Huang, W.J., Tian, H., Ren, W., and Zang, Z.: Modeling $p \mathrm{CO}_{2}$ variability in the Gulf of Mexico, Biogeosciences, 13, 4359-4377, https://doi.org/10.5194/bg-13-4359-2016, 2016.

Zavala-Hidalgo, J., Gallegos-García, A., Martínez-López, B., Morey, S. L., and O'Brien, J. J.: Seasonal upwelling on the western and southern shelves of the Gulf of Mexico, Ocean Dynam., 56, 333-338, 2006. 